\title{
TWO-SIDED MARKETS AND THE CHALLENGE OF TURNING ECONOMIC THEORY INTO ANTITRUST POLICY
}

\author{
DiRK AUER* AND NiCOLAS PETIT **
}

\begin{abstract}
The award of the Nobel Prize in Economics to Professor Jean Tirole in 2014 has generated intense interest about his brainchild theory of two-sided markets. Against this background, this paper explores whether there is such a thing as a unified theory of two-sided markets and whether the two-sided markets literature can readily be applied by antitrust agencies, regulatory authorities and courts. This paper vindicates caution. The buzz surrounding two-sided markets could mask the fact that, in many cases, the policy implications of the theory are not yet clear, and that divergences among its proponents are often underplayed. In that regard, the paper notably stresses that one of the key conditions of market two-sidedness identified by Rochet and Tirole in their seminal paper of 2003 - the unavailability of Coasian bargaining between both sides of a platform - has often disappeared from subsequent scholarship. This omission threatens the coherent implementation of the theory of two-sided markets. Without this qualification, markets are often mischaracterized as two-sided, as soon as they display prima facie signs of indirect network externalities.
\end{abstract}

KEY WORDS: antitrust, competition law, two-sided markets, Coase theorem, payment platforms, Microsoft, e-books

\section{INTRODUCTION}

This paper discusses the two-sided markets theory in an antitrust context. At its core, the theory finds that in markets where platforms interact with distinct groups of users, total output is influenced by the allocation of prices between the various groups. This finding marks a departure from the Structure-Conduct-Performance ("SCP") paradigm which has informed decades of applied antitrust policy across the world. ${ }^{1}$

Today, the theory of two-sided markets is one of the most widely discussed topics in modern industrial organization ("IO") scholarship. Hundreds of academic papers have been written

\footnotetext{
*Research fellow and PhD Student, University of Liège (ULg), Liege Competition and Innovation Institute (“LCII”). dirk.auer@ulg.ac.be

***Professor, University of Liege (ULg), Liege Competition and Innovation Institute (“LCII”).Nicolas.petit@ulg.ac.be.

${ }^{1}$ The SCP paradigm remains a prominent foundation for the formulation of antitrust policy. This, however, is not to deny advances and refinements brought to the SCP paradigm, in particular with the introduction of game theory in antitrust literature.
} 
about it in the last ten years ${ }^{2}$. And several of those papers have entered the antitrust literature, insisting on the potential of the two-sided markets theory to inform antitrust policy and regulation. ${ }^{3}$ Whilst scholars are still divided as to the relevance of the theory across all areas of antitrust policy, most tend to agree on its inherent contribution to the enforcement of antitrust law, in particular in the digital economy. ${ }^{4}$

Conceivably, this novel field of academic work will sooner or later filter through practice. The economics-driven nature of the antitrust process is favorable to the importation of IO developments in real life cases. As Kimble v Marvel Entertainement LLC recalled, the US Supreme Court "has felt free to revise [its] legal analysis as economic understanding evolves and to reverse antitrust precedents that misperceived a practice's competitive consequences". 5 At one point or the other, stakeholders - economic consultants, lawyers, lobbyists and governments - will invite antitrust agencies, courts and regulators to pass judgment on twosided markets arguments. In a more distant future, agencies and regulators may even attempt to derive general policy guidelines from two-sided markets literature. ${ }^{6}$ Whilst, some scholars

${ }^{2}$ See David S. Evans \& Richard Schmalensee, The Antitrust Analysis of Multi-Sided Platform Businesses (Nat'l Bureau of Econ. Research, Working Paper No w18783, 2012). Evans and Schmalensee have counted more than 200 papers on multi-sided platforms.

${ }^{3}$ See, for instance, Bernard Caillaud \& Bruno Jullien, Chicken \& Egg: Competition among Intermediation Service Providers, 34 RAND J. ECON., No. 2, 309, 309-28 (2003). The authors consider that "the design of competition policy rules with respect to such markets should take these characteristics into account".

${ }^{4}$ Some scholars find the theory to be relevant across the board, including in relation to exclusionary conduct. See Schmalensee and Evans, supra note 2. Others argue that two-sided markets theory will mainly grow in importance in relation to pricing issues such as aggressive price competition in single firm conduct cases, market definition and the SSNIP test in merger control, etc. See Marc Rysman, The Economics of Two-Sided Markets, 23 J. ECON. PerspeCtives, No. 3, 125, 125-143 (2009). Although there are some exceptions, only a few papers identify theories of harm specific to two-sided markets. See Massimo Motta \& Helder Vasconcelos, Exclusionary Pricing in a Two-sided Market (Centre for Econ. Pol'y Research, Discussion Paper No 9164, 2012).

${ }^{5}$ Kimble v. Marvel Entertainment, LLC, 576 U.S. (2015).

${ }^{6}$ See notably a report by the German monopoly commission. Monopolkommissie, Competition policy: The challenge of digital markets (Special Report by the Monopolies Commission pursuant to Section 44(1)(4) ARC, 1 June 2015), http://www.monopolkommission.de/images/PDF/SG/SG68/S68_summary.pdf (the report sets out a number of challenges relating to antitrust enforcement in two-sided markets, which could potentially lead to the establishment of more formal guidelines). 
like Josh Wright and Janusz Ordover have cautioned against a premature policy implementation of two-sided markets theory ${ }^{7}$, their voice remains marginal in the literature.

Our paper seeks to take a stance in this debate. Its goal is to identify what the theory of twosided markets has to offer to competition agencies, and the challenges they may face when trying to apply the theory's core findings.

To explore those issues, the paper is structured as follows. Following this introduction, Section II tries to ascertain the place occupied by two-sided markets theory in the industrial organization literature (II). We find that there is, to date, no unified theory of two-sided markets. On the contrary, we document serious conceptual divergences amongst its proponents. Section III, in turn, investigates the place of the two-sided markets theory in modern antitrust policy in the US and the EU (III). We review two types of unilateral and coordinated conduct cases. We first look at cases where the decision-maker explicitly took account of the theory of two-sided markets to resolve the case. We then discuss cases where the theory did not ostensibly influence the decision-maker, despite its possible relevance to the main proceedings. This investigation in positive antitrust policy ultimately helps cast light on the added-value that the two-sided markets theory brings to practice. Section IV concludes (IV). It finds that two-sided markets theory has brought a number of practical contributions in applied antitrust policy, even though a number of challenges remain. Some of these challenges would be overcome if a more cohesive theory of two-sided markets were developed.

\section{THE THEORY OF TWO-SIDED MARKETS AND ITS PLACE IN THE INDUSTRIAL ORGANIZATION LITERATURE}

This section explains that the two-sided markets theory is a refinement of traditional IO theory (A). It then shows that from an operational standpoint, the theory is still in a state of flux, for many of its definitions and concepts remain unsettled (B). Lastly, it suggests that more work is needed, if the theory is ever to usher in a unified and mature normative framework (C).

${ }^{7}$ See, notably, the statement of Joshua Wright, Commissioner of the FTC. Ron Knox, Wright: Guidance on two-sided markets may prove difficult, Global Competition Review, 11 February 2013, http://globalcompetitionreview.com/news/article/33038/wright-guidance-two-sidedmarkets-may-prove-difficult/. See also Janusz Ordover, Comments on Evans \& Schmalensee's 'The Industrial Organization of Markets with Two-Sided Platforms', 3 COMPETITION POL'Y INT'L, No. 1, 181, 181-89 (2007), (Ordover argues that there is still much work to be done on the topic of two-sided markets). 


\section{A. EPISTEMOLOGICAL ASSESSMENT}

1. The Classic Descriptive Ambition of Two-Sided Markets Theory

The essence of industrial organization is to study the effects of distinct forms of industry structure on price and output levels. Monopoly theory posits that a single supplier will charge a higher price than the market demands, causing a deadweight loss as valuable output is not produced (allocative inefficiency). The theory of perfect competition finds that atomistic suppliers will serve at the lowest possible price, producing all the requested output (allocative efficiency). Oligopoly theory suggests that when there are only a few suppliers, other factors influence price levels, in several possible directions (between the monopoly and the perfect competition level).

These questions were studied by early scholars like Marshall ${ }^{8}$, Cournot $^{9}$, Bertrand ${ }^{10}$, Chamberlin ${ }^{11}$, Mason ${ }^{12}$ and Robinson ${ }^{13}$, from the end XIXth century to the mid XXth century ${ }^{14}$. They have also been on the research agenda of Harvard ${ }^{15}$, Chicago $^{16}$ and Post-Chicago

\footnotetext{
${ }^{8}$ See notably Alfred MARSHALl, PrinciPLES OF ECONOMICS (1890).

${ }^{9}$ See notably ANTOINE Augustin COURNOT, RECHERCHES SUR LES PRINCIPES MATHÉMATIQUES DE LA THÉORIE DES RICHESSES (1838).
}

${ }^{10}$ See notably Joseph Louis François Bertrand, Book review of theorie mathematique de la richesse sociale and of recherches sur les principles mathematiques de la theorie des richesses, 67 JOURNAL DE SAVANTS, 499-508 (1883).

11 Edward Hastings Chamberlin, The Theory of Monopolistic Competition: A ReORIENTATION OF THE THEORY OF VALUE ( $1^{\text {st }}$ ed., 1927).

${ }^{12}$ Edward S. MAson, The Corporation In Modern Society (1959).

${ }^{13}$ JOAN ROBINSON, THE ECONOMICS OF IMPERFECT COMPETITION (1933).

${ }^{14}$ See T.A.B. Corley, Emergence of the Theory of Industrial Organization, 1890-1990, 19 Bus. $\&$ ECON. HIST., Papers presented at the thirty-sixth annual meeting of the Business History Conference, 83, 83-92, (1990).

${ }^{15}$ See notably Joe S. BAIn, Price TheOry (1952). See Joe S. Bain, Relation of Profit Rate to Industry Concentration: American Manufacturing, 1936-1940, 65 Q. J. ECON., No. 3, 293, $293-$ 324 (1951). See also Phillip E. Areeda \& Herbert Hovenkamp, Donald F. Turner,

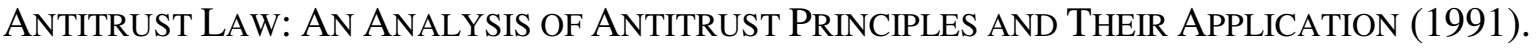

16 See notably George J. Stigler, The Theory of Price (4 $4^{\text {th }}$ ed.1987). See also Robert H. Bork, The Antitrust Paradox (illustrated reprint 1993) (1978). See also Richard A. POSNER, ANTITRUST LAW ( $2^{\text {nd }}$ ed., 2001). 
scholars ${ }^{17}$ since the second half of the XXth century though with distinct methodologies Harvard scholars used empirical measurements, Chicago scholars favored formal reasoning, while many Post-Chicago scholars rely on game theoretic frameworks and focus on the organization of industry structure in the broad sense, including in terms of firms' strategy, product characteristics, customer preferences, government interference, etc.

This is the fundamental level at which the theory of two-sided markets is often said to cut through. Originally, the theory can be traced to three papers by Caillaud and Julien ${ }^{18}$, Rochet and Tirole ${ }^{19}$, and Armstrong ${ }^{20}$, published in the years 2003 to 2006. The best presentation of the theory begins with the idea that in some markets, profit-seeking manufacturers who wish to remain competitive vie to get two separate groups of users "on board". The case of console and video games producers is often used as an illustration. In this market, no developer would produce games for a console that has no gamers. Likewise, no gamer would buy a console if there were no compatible games (and thus developers). According to the theory of two-sided markets, a solution to this "chicken and egg" problem is for the console manufacturers to "choose a price structure and not only a price level". ${ }^{21}$ This decision is not benign in terms of output. In their 2006 paper, Rochet et Tirole find that for a given (total) price level, output can increase "by charging more to one side and less to the other relative to what the market delivers" 22 . One side (gamers) also known as the "money side" 23 will be called to cross-

${ }^{17}$ JEAN TIROLE, THE THEORY OF INDUSTRIAL ORGANIZATION (1988).

${ }^{18}$ Caillaud \& Jullien, supra note 3.

${ }^{19}$ Jean-Charles Rochet \& Jean Tirole, Platform Competition in Two-Sided Markets, 1 J. EuR. ECON. Association, No. 4, 990, 990-1029 (2003).

${ }^{20}$ Mark Armstrong, Competition in Two-Sided Markets, 37 RAND J. ECON., No. 3, 668, 66891 (2006).

${ }^{21}$ Jean-Charles Rochet \& Jean Tirole, Two-Sided Markets: A Progress Report, 37 RAND J. ECOn., No. 3, 645, 648 (2006). See also Daniel F. Spulber, Solving the Circular Conundrum: Communication and Coordination in internet Markets, 104 Nw. U. L. REV., No. 2, 537, 537592 (2010), (Spulber talks of a "circular conundrum").

${ }^{22}$ Rochet and Tirole, supra note 21 , at 648.

${ }^{23}$ Console manufacturers typically earn royalties from each game that is sold. These royalties, ultimately paid by gamers, appear to make up the bulk of console manufacturer's earnings. See 
subsidize the participation of the other side (developers), also referred to as the "subsidy side" 24 . In such settings, the "decomposition or allocation" of the total price between the two sides will affect output.

From an epistemological perspective, this is the theory's central finding. Allocative efficiency can be improved by changes to the price structure, and not only by changes to its level. But is this really revolutionary from a theoretical standpoint?

Rochet and Tirole themselves cautioned against this reading. In their 2006 paper, they explained that the fact that the price structure affects economic efficiency is a "widespread belief" and already a "premise" for many policy interventions. In reality, Rochet and Tirole did not seem to articulate a normative analysis of two-sided markets but instead, as Stigler once wrote $^{25}$, they sought, "to explain economic life" in continuance of the positive tradition of IO scholarship In this context, their seminal 2003 paper primarily pursued a descriptive ambition. 26 It explored how platforms in distinct environments allocate prices between the two sides of the market.

Their 2006 paper followed the same descriptive purpose, but pushed it one step further by attempting to provide a stylized definition of two-sided markets, and of the necessary conditions for their existence. ${ }^{27}$ In this context, it is now undisputed that there must be indirect network externalities (or cross-platform externalities) to have a two-sided market: users' participation on one side increases the participation of users on the other side (and vice versa). In other words, the price structure must be "non neutral". In addition - and of equal importance-Rochet and Tirole argue that users must be prevented from negotiating away the platform's price

notably Julia Wood, Teardown of Xbox, PS4 reveal tight margins, CNBC (Nov. 27, 2013, 3.13 AM), http://www.cnbc.com/id/101230904.

${ }^{24}$ A developer kit for Sony's new PS4 console usually costs as little as $\$ 2500$ and is sometimes given to developers free of charge. See Colin Campbell, So how much does it cost to develop for PlayStation 4?, PoLYGON (Jul. 24, 2013), http://www.polygon.com/2013/7/24/4553842/sohow-much-does-it-cost-to-develop-for-playstation-4.

${ }^{25}$ George J. Stigler, Law or Economics?, 35 J. L. \& ECON., No. 2, 455, 463.

${ }^{26}$ Rochet \& Tirole, supra note 19.

${ }^{27}$ See Rochet \& Tirole, supra note 21 , at 648. 
allocation through Coasian bargaining or thanks to monopoly power. ${ }^{28}$ As we highlight below $^{29}$, this last limb of the definition has been somewhat ignored in more recent scholarship. Importantly, the subsequent IO literature that sought to build on Rochet and Tirole also followed a descriptive approach. For instance, the oft-quoted 2006 Armstrong paper underscores three main factors that determine the price structure of a platform: the relative size of cross-group externalities, fixed fees or royalties, and presence of single or multi-homing. ${ }^{30}$ Armstrong further attempted to explain which side pays more and less in terms of externalities (the side that brings the biggest positive externalities to the other pays less).

\section{ALTERNATIVE WELFARIAN READING}

Even if one were to read two-sided market theory in a welfarian perspective, the thrust of the theory - that the overall "price level" is not the sole determinant of output - is an old economic idea. The conventionality of this finding is best illustrated by price discrimination theory. Much like price allocation in two-sided markets, charging differentiated prices to consumers can increase output and promote efficiency. ${ }^{31}$ Third-degree price discrimination by movie theaters is a case in point. ${ }^{32}$ Movie theaters increase output when they apply different prices to parents and children. Arguably, price discrimination also seeks to "get all users on board". This view, however, is not universally accepted. Parker and Van Alstyne, for example, have disputed the analogy between price discrimination and two-sided markets. They note that third degree price discrimination differentially extracts surplus from consumers and transfers it to the seller. Instead, in two-sided markets, they posit that surplus is transferred from a seller on one side of a platform - to consumers on the other side, potentially increasing consumer

${ }^{28} I d$. at 649 . In other words, there must be transaction costs preventing "the bilateral setting of prices between buyer and seller".

${ }^{29}$ See section II.B.1 (which concerns the various definitions given to two-sided markets).

${ }^{30}$ Armstrong, supra note 20, at 668-70.

${ }^{31}$ William J. Baumol \& David F. Bradford, Optimal Departures From Marginal Cost Pricing, 6 AM. ECON. ReV., Issue 3, 265, 267 (1970).

${ }^{32}$ Barak Orbach \& Linar Einav, Uniform prices for differentiated goods: The case of the movietheater industry, 27 INT'L REV. L. \& ECON., 129, 129-153 (2007). 
demand and generating extra surplus on the seller side. ${ }^{33}$ That argument, however, is not compelling. In many two-sided markets, no surplus is transferred from a seller to a user, but instead wealth is being asymmetrically distributed across distinct categories of users (or customers), for instance, for cross subsidization purposes. Night clubs are the best example. There are two categories of users (males and females) on each side of the platform, and they pay distinct prices. More generally, when there are "positive indirect network effects", i.e. when both sides bilaterally enjoy additional surplus by virtue of the presence of the other (in payment cards, night clubs and video consoles for instance) the sort of unidirectional surplus transfer observed by Parker and Van Alstyne does not happen.

Another objection to the analogy might be that in a standard price discrimination setting, there are (at least) two prices. In contrast, in a typical two-sided markets scenario, there is just one price: the money side pays (i.e., advertisers on Google's search engine), and the subsidy side pays nothing (i.e., users of Google's search engine). However, it is readily apparent that this counterargument is deficient. First, in real life markets, many two-sided businesses charge prices on both sides. Or put differently, the subsidy side often pays a price to the platform, even if it bears less of the platform's costs than the money side (for instance, ladies in night clubs are often charged a discounted entrance fee). A second - and fatal - weakness of this counterargument is that it is overly formalistic. An alternative reading of a two-sided markets where a free service is given on the subsidy side may be that users are paying a hidden, nonmonetary price. For instance, users of Google's search engine can be deemed to pay in kind, when they read adverts and give away personal data to the other side of the platform. ${ }^{34}$

In making the above points, we just want to recall that economists have long known that cost allocation can influence output. And this finding pervades well beyond IO. Regulatory economics shows for instance that, in industries with common costs, Ramsey pricing expands output. Under Ramsey pricing, the service provider structures prices so that they are inversely proportional to users' price elasticity. ${ }^{35}$

${ }^{33}$ Geoffrey Parker \& Marshall W. Van Alstyne, Two-Sided Network Effects: A Theory of Information Product Design, 51 Management ScI., No. 10, 1494, 1497 (2005).

${ }^{34}$ See Giacomo Luchetta, Is the Google Platform a Two-Sided Market? (30 April, 2012) (unpublished manuscript), http://papers.ssrn.com/sol3/papers.cfm?abstract_id=2048683.

35 See Jean-Jacques Laffont \& JeAn TiRole, Competition in Telecommunications 60 (2001). 
Similarly, in the economics of justice, Rawls' "maximin" principle tolerates differences in price allocation, provided they are to the advantage of all (the pie increases) and that the welfare of the worst off is as large as feasible (the share of the pie). ${ }^{36}$ In other words, that firms accept to pay more than others in exchange for additional utility/output is mundane economics.

\section{TWO-SIDED MARKETS THEORY AND OTHER IO THEORIES}

Turning from a welfarian to an operational perspective, several important features of two-sided markets theories build on other well-known IO concepts. To begin, the theory of network externalities that was formulated in the 1980s provided the main economic intuitions on which two-sided markets theory runs (Katz and Shapiro, 1985 and 1986). ${ }^{37}$ The theory of network externalities shows that the individual utility that one user derives from a good may raise with the number of other users that consume it. The canonical example is that of communications networks. Increases to the number of users connected to the network multiply the number of connections that can be made on the network exponentially. This can ultimately increase the individual value of the network for each user.

Seen in this context, the theory of two-sided markets looks again like a derivative - albeit a significant one - of the mainstream theory of network externalities, with the twist that two distinct user groups are present on opposite sides of a platform. And the experience of agencies seems to corroborate our reading. Although the theory of two-sided markets was the first to formalize these cross-platform externalities, authorities had intuitively identified and understood them before the emergence of economic models of two-sided markets. ${ }^{38}$

${ }^{36}$ See Edmund S. Phelps, Taxation of Wage Income for Economic Justice, 87 Q. J. Econ., No. 3, 331, 331-354 (1973). See John RAWLs, A ThEORY OF JusticE (1971) (though Rawls was not speaking, strictly, of pricing structures but rather of the distribution of income and wealth in society).

${ }^{37}$ See Michael L. Katz \& Carl Shapiro, Network Externalities, Competition, and Compatibility, 75 Am. ECon. ReV., 424, 424-440 (1985). See also Michael L. Katz \& Carl Shapiro, Technology Adoption in the Presence of Network Externalities, 94 J. POL. ECON., 822, 822-841 (1986).

${ }^{38}$ Ordover, supra note 7, at 182 . In that respect, the US Microsoft case contains a particularly prescient quote. For a full discussion of this case and its implications see section III.B.1, in particular note 185 . 
But even more fundamentally, the theory of two-sided markets is firmly rooted in Coasian economics. At its heart, the Coase theorem sought to propose "a theory to handle the problem of harmful effects" posed by the actions of business firms on others (e.g. the cattle raiser that destroys crop on neighboring land). ${ }^{39}$ In his seminal 1960 paper "The Problem of Social Cost", Coase explained that Government regulation (e.g. tax or regulation) was not the sole and whole remedy to such negative externalities. ${ }^{40}$ He sought to explain that the problem of social cost is the problem of "choosing the appropriate social arrangement for dealing with the harmful effects". ${ }^{41}$ And Coase notoriously found that if property rights are well delimited and there are no transaction costs, private bargains between firms can lead to an optimal allocation of resources.

With this background, the early two-sided markets papers explain that the platform's output effect only exists when Coasian bargaining amongst users cannot take place, thereby suggesting that two-sided markets only exist in a "non-Coasian" world. ${ }^{42}$

But this is an incomplete reading of the research of Ronald Coase. Interestingly, in section VI of his 1960 paper $^{43}$, Coase envisioned alternatives to government regulation and private bargains when the cost of market transactions is high. As early as 1937, Coase had already stated in the Nature of the Firm that vertical integration could be an alternative. And in his 1960 paper, he exhorted economists "to study the work of the broker in bringing parties together", as a possible alternative. Though the reference is subtle, it is clear that Coase had foreseen, though in embryonic terms, the role of platforms as a "social arrangement" likely to resolve externalities. The point is that two sided markets are a special version of the private ordering mechanisms anticipated by Coase to address transaction cost problems. Schmalensee and Evans say just this when they contend that two-sided markets create value by "solving a

\footnotetext{
${ }^{39}$ Ronald H. Coase, The Problem of Social Cost, 3 J. L. \& EcON., 1, 1 (1960).

${ }^{40} I d$.

${ }^{41}$ Coase, supra note 40 , at 19 . See also GeOrge J. Stigler, The Theory of Price $117-22$ ( $4^{\text {th }}$ ed. 1987)
}

${ }^{42}$ See Rochet \& Tirole, supra note 21, at 649, (according to Rochet \&Tirole a market is not two-sided when the Coase theorem applies). See also Parker \& Van Alstyne, supra note 33, at 1497.

${ }^{43}$ Coase, supra note 39 , at 15. 
coordination - and transaction cost - problem between the groups of customers". ${ }^{44}$ To suggest that two-sided markets exist in a non-Coasian world might thus be an overstatement.

This same point was made by Spulber in an undeservedly less famous paper. Spulber argues that the "decentralized coordination" that occurs between each group of users through the platform relates to "Ronald Coase's description of private bargaining as a means of resolving the problem of social cost". ${ }^{45}$ In Spulbers' opinion, two-sided markets belong to the world of Coasian bargaining, because there is an accumulation of bilateral transactions between seller and intermediary, and between intermediary and buyer. This contradicts Rochet and Tirole's crucial point that two-sided markets do not belong to the world of Coasian bargaining because some factors prevent users from reengineering or evading the effects of the price structure decided by a platform (as with tax incidence). ${ }^{46}$

Both views might not be mutually exclusive though. Two-sided markets exist because of costs that would otherwise prevent parties from concluding direct bilateral transactions. They are thus a Coasian "social arrangement" that solves parties' inability to conclude "bilateral transactions". In turn, this social arrangement can lead to a series of Coasian bargains between users on each side of the platform, if users re-engineer the platform's pricing decisions (when this is the case, there is no two-sided market). Clearly, the theory of two-sided markets owes much to the work of Ronald Coase.

\section{B. CONCEPTUAL PROLIFERATION}

Initially, the theory of two-sided markets ambitioned to have a well-defined scope. Rochet and Tirole (as well as other early work) had cautiously underscored the specificities of their analysis and the necessity "to circumscribe the scope of a two-sided markets theory". ${ }^{77}$ But the subsequent development of a vast literature on two-sided markets theory may have achieved the exact opposite result. A manifest symptom of this is the myriad of labels that have been

\footnotetext{
${ }^{44}$ Evans \& Schmalensee, supra note 2 at 7.

${ }^{45}$ Spulber, supra note 21, at 544.

${ }^{46}$ Rochet \& Tirole, supra note 21, at 649.

${ }^{47}$ Rochet \& Tirole, supra note 21, at 664.
} 
tagged on "two-sided markets" 48 in subsequent scholarship, possibly with the intention of better capturing the dynamics of those markets: "multi-sided platforms"49, "two-sided networks"50, "informational intermediation" $"$, or "two-sided strategies" 52 .

In this section, we attempt to document this expansion under a more itemized perspective. We show first that the scholarship is not united at the definitional level (1). We then discuss several core concepts of two-sided markets theory which have also received heterogeneous interpretations and denominations (2). Last, we use concrete illustrations to show that the scholarly effervescence that surrounds the theory of two-sided markets has consequences which go beyond semantics. In particular, the present state of doctrinal proliferation risks misleading policy makers and enforcers, leading to unsound applications of the law (3).

\section{DEFINITIONS}

A recurring topic in the sided markets literature concerns the definition of two-sided markets, and their differences with one-sided markets. ${ }^{53}$ Rochet and Tirole explained early that "you know it when you see it"-type definitions would be inappropriate. ${ }^{54}$ And an increasing number of papers have sought to propose stepwise methods for the identification of two sided markets ${ }^{55}$. In the scholarship, three types of definitions have been particularly popular. The first, and the narrowest, is the one of Rochet and Tirole: a "market is two-sided if the platform can affect the volume of transactions by charging more to one side of the market and reducing the price paid

${ }^{48}$ Rochet \& Tirole, supra note 19; Julian Wright, One-Sided Logic in Two-Sided Markets, 3 REV. NETWORK ECON., Issue 1, 44, 44-64 (2004); Rysman, supra note 4.

${ }^{49}$ Evans and Schmalensee, supra note 2.

${ }^{50}$ Thomas R. Eisenmann, Geoffrey Parker, G. \& Marshall W. Van Alstyne, Strategies for TwoSided Markets, HARV. Bus. REV., Oct. 2006. See also Parker \& Van Alstyne, supra note 33.

${ }^{51}$ Caillaud \& Jullien, supra note 3.

${ }^{52}$ Rysman, supra note 4.

${ }^{53}$ A notable exception is Rysman, who explains that this question may not be so important. See Rysman, supra note 4, at 127.

${ }^{54}$ Rochet \& Tirole, supra note 21 , at 645.

55 Lapo Filistrucchi, Damien Geradin \& Eric van Damme, Identifying Two-Sided Markets (Tilburg Law School Research Paper, No. 008/2012, 2012), http://ssrn.com/abstract=2008661. 
by the other in an equal amount; in other words, the price structure matters, and platforms must design it so as to bring both sides on board" "It. It focuses on the price structure. Interestingly, Rochet and Tirole complemented this with a definition of one-sided markets: "The market is one-sided if the end-users negotiate away the actual allocation of the burden (i.e., the Coase theorem applies); it is also one-sided in the presence of asymmetric information between buyer and seller, if the transaction between buyer and seller involves a price determined through bargaining or monopoly price-setting, provided that there are no membership externalities". ${ }^{57}$

A second, "less formal" definition has been proposed by Evans and Schmalensee 58 : "a multisided platform" has "two or more groups of consumers"; "who need each other"; "who cannot capture the value of their mutual attraction"; and "rely on a catalyst to facilitate" their interaction. This definition has a managerial savor. It insists on the transactional remedy derived from the platform.

A third definition considers that there is a two-sided market when there is "some kind [emphasis added] of interdependence or externality between groups of agents that are served by an intermediary". 59 This strand of the literature mostly pays attention to the existence of an "indirect network externality" across a platform. To our understanding, it is the broadest definition that can be encountered in two-sided markets scholarship.

Selecting the optimal definition for two-sided markets is not a trivial issue. We may approach its importance by contrasting Rochet and Tirole's definition with the two other definitions. Rochet and Tirole restrict two-sided markets to situations where Coasian bargaining between both sides of a platform is impossible. This requirement is absent from the two other definitions, but has profound implications. Let us take the example of two close yet distinct businesses, i.e. supermarkets and shopping malls. The Coasian bargaining requirement leads to interesting results. In the case of supermarkets, suppliers cannot bargain with consumers and pass through the platform's allocation of costs. This is because, in most cases, it is the supermarket (i.e. the platform) that sets the retail price. Supermarkets are thus two-sided

\footnotetext{
${ }^{56}$ Rochet \& Tirole, supra note 21 , at 664.

${ }^{57} I d$. at 665 .

${ }^{58}$ Evans \& Schmalensee, supra note 2, at 7.

${ }^{59}$ Rysman, supra note 4, at 126.
} 
markets in Rochet and Tirole's sense. The same conclusion, however, cannot apply to shopping malls even though they are, at least at first glance, a similar business model. Here, consumers and stores can modify the shopping mall's (i.e. the platform) pricing decisions, by bargaining over the retail prices which are set by stores. Shopping malls are thus one-sided markets under Rochet and Tirole's definition. However, both supermarkets and shopping malls would be treated as two-sided markets under the two other definitions. Under the second definition, it is clear that supermarkets and shopping malls solve a transactional problem between suppliers and consumers. Likewise, under the third definition, supermarkets and shopping malls address an indirect network externality: the more brands associated to the platform, the more consumers want to join the platform, and vice-versa.

Moreover, under the Rochet and Tirole definition, parameters that are not readily observable play a critical role in identifying a two-sided market. Take supermarkets again. Whist they are generally a form of two-sided market in our above example, the conclusion changes if there is resale price maintenance. In this variant, the supermarket cannot structure prices, for the contract provides that it is the supplier who sets the price that is charged to consumers. Clauses introduced in the distribution contract between a supplier and a supermarket may thus turn a two-sided market in a one sided market under Rochet and Tirole's definition. ${ }^{60}$ In contrast, under the other two definitions, those issues are entirely irrelevant, and supermarkets would most probably be qualified as two-sided markets, regardless of such contractual arrangements.

Beyond contractual restrictions, other factors like a platform's governance structure, or even the legal system may have a decisive impact on the availability of Coasian bargaining between users, and affect its one or two-sided nature. Though they have much intuitive appeal, definitions that focus primarily on the intermediation remedy provided by the platform - like the second - or that insist on cross-group externalities - like the third - turn a blind eye on such features. In so doing, they might be over inclusive and the cause of errors when introduced into antitrust policy (type I). Conversely, those definitions may discard the existence of a two-sided

\footnotetext{
${ }^{60}$ Payment cards and "surcharging" offer another example. "Surcharging" is a merchant's ability to make cardholders pay for the transaction fees that it owes to the payment card platform as a result of a payment card being used. If a platform's rules forbid surcharging, then it is the platform that controls which side will bear most of the platform's costs and both sides probably cannot bargain away this allocation. Instead, if surcharging is allowed, the party with the most bargaining power can shift part or all of the costs to the other party, thus overturning the price allocation decided by the platform.
} 
market because the cross-group externality is not readily observable, and it is the platform's pricing policy that will generate it endogenously. ${ }^{61}$ In such cases, the definition will be underinclusive, and generate another kind of error (type II).

This is not to say, however, that definitions that condition a finding of two-sidedness on the absence of Coasian bargaining are flawless. Whilst they seem less prone to type I errors, they remain potentially under-inclusive. For instance, if one takes Rochet and Tirole's focus on the pricing structure literally, then free markets where one side does not pay (e.g., free newspapers and more generally advertising markets) ought to be reputed as one sided market, for there is no price structure on such markets. What is more, such definitions generate decisional costs. ${ }^{62}$ Under Rochet and Tirole's definition, it is indeed necessary to gauge the intensity of Coasian pass through to determine if the market is two sided. And as Fillistrucchi et al put it, "the lower the pass through, the more important the two sided nature of the market". ${ }^{63}$ But there is no predefined pass through threshold at which a market vacillates from two-sidedness into onesidedness. Market multi-sidedness is thus a matter of degree. And the process of deciding if a market is two-sided risks being warped by endless discussions and will eventually involve a certain arbitrariness. Surely, this remark does not apply to markets of the "media type", where no transaction takes place between the two sides (advertiser and viewer), and where there is presumably no pass through. However, it remains pertinent for markets of the "payment cards type", where a transaction takes place between the two sides (merchant and shopper).

Whichever the right definition may be, much work thus remains to be done to elicit a cohesive understanding of two-sided markets.

\section{CONCEPTS}

Divergences also appear at a more granular level. In the literature, there is a tendency to abandon classic IO concepts in favor of novel notions. This can be observed in relation to the very notion of a "market" (2.1), but also in relation to those of "supply" and "demand" (2.2). Again, the issue is not merely rhetorical.

\subsection{MARKETS}

\footnotetext{
${ }^{61}$ See Rochet \& Tirole, supra note 21 , at 657-58.

${ }^{62}$ Frank H. Easterbrook, The Limits of Antitrust, 63 TEX. L. REV., No.1, 1, 16 (1984).

${ }^{63}$ Filistrucchi et al. supra note 55, at 11.
} 
In the early literature, papers were rife with references to two-sided "markets" level. As matters stand today, the literature has replaced (or qualified) the "market" concept with a pattern of references to other concepts, often encountered in the business and tech literatures. Evans and Schmalensee talk of multi-sided "platform businesses" 65 or "markets with two-sided platforms" $"$. Parker and Van Alstyne resort to the concept of two-sided "networks". 67

A common thread to those papers is to stress the importance of the platform. The new wording may seek to address the critique that the notion of a two-sided market is tautological, for all markets are two-sided as long as there is a buyer and seller ${ }^{68}$.

The best wording is unclear in our view, and there are good arguments in support of platformtype semantics (we actually use platform abundantly in this paper). However, one line of argument strongly cautions against the use of platform language, and militates in favor of the traditional IO specification. The concept of "platform" indeed invites another equally tautological inference, i.e. that some sectors/businesses are intrinsically multi-sided. ${ }^{69}$ After all, in plain language, a platform is "a raised level surface", with several sides: an above and a below.

From an economic perspective, however it is not always true that a platform is necessarily multi-sided. For instance, it is customary to view payment card systems as platforms. However, although many payment systems - notably Visa, MasterCard and American Express - are set up as two-sided markets, this is not always the case. Many supermarket chains for

${ }^{64}$ Rochet \& Tirole, supra note 19; Armstrong, supra note 20.

${ }^{65}$ Evans \& Schmalensee, supra note 2.

${ }^{66}$ David S. Evans \& Richard Schmalensee, The Industrial Organization of Markets with TwoSided Platforms, 3 COMPETITION POL'Y. INT'L., No.1, 151-79 (2007).

${ }^{67}$ Parker \& Van Alstyne, supra note 33.

${ }^{68}$ Ordover supra note 7 , at 181.

${ }^{69}$ In plain language, a platform is "a raised level surface", with several sides: an above and a below. 
instance provide their customers with an in-house payment card system. ${ }^{70}$ At first blush, such card systems are not two-sided markets, because the platform owner does not sit between two separate groups of users. ${ }^{71}$ In addition, even if supermarkets were to subsidize cards to induce adoption by shoppers as in the plain-vanilla two-sided market scenario, supermarkets retain the ability to charge shoppers for their use of the store's payment system through discrete increases in retail prices. In this case, the purchases of other shoppers that do not use cards will contribute to the purchases of shoppers that use cards. However, it seems far-fetched to distinguish shoppers on this basis, and to view them as the two distinct sides of the payment platform. Under this logic, any investment of a supermarket in favor of a category of shoppers would precipitate the exacting conclusion that it is a two-sided platform.

In addition, from a policy perspective, the random, side-by-side combination of business or tech journals' semantics with classic economics terminology may send the counterproductive signal that the theory is not mature. If the theory is ever to be embedded in antitrust and regulation, it is probably advisable to frame it in terms that fit readily with accepted terminology in those fields.

\subsection{BUYER/SELLER (OR SUPPLY/DEMAND)}

The literature on two-sided markets is replete with references to "users" or to "groups of users". On a close read, those users refer to the well-known IO concepts of "buyers" and "sellers" (or of "supply" and "demand"). In their papers, Rochet and Tirole as well as others, often alternate between those two notions. $^{72}$

There are several reasons that plausibly explain authors' indistinct use of both the IO "buyerseller" couple and the "users" concept. One is that in a significant number of two-sided markets, users on one side are bartering with the platform so that there is no monetary transfer (for instance, in search engines where users accept to view adds and share their personal data in exchange for information). In-kind payments, freebies and subsidies are hard to fit into the buyer-seller dichotomy. Hence the recourse to the generic concept of a "user". Another is that

\footnotetext{
${ }^{70}$ Target, for example, offers an in-house payment card that can only be used in its stores. See http://www.target.com/redcard/main\#next (last visited August 24, 2015)

${ }^{71}$ Evans \& Schmalensee, supra note 2, at 13.

72 Rochet \& Tirole, supra note 19. Talking, besides buyers and sellers, of "distinct group of users" or "two distinct sides".
} 
in certain two-sided markets, some groups of users pay a price to the platform whereas others do not, so they cannot be considered as buyers (for instance, male and female attendants of a nightclub).

In the scholarship, there seems to be a broad understanding that the use of either terminology has at best innocuous consequences, and that all users can $a$ priori be considered buyers and/or sellers. ${ }^{73}$ The user that pays no price in dealing with the platform (or that barters with it), is a buyer that receives a "negative price" (a subsidy or a "freebie") as compared to other buyers on other sides who are charged a "positive price".

With this background, it is tempting to dismiss as formalistic the relevance of the "buyer-seller" v "user" dichotomy. But, treating those concepts as substitutes could ultimately prove misleading. This is best illustrated with a thought experiment. If one thinks of the economy as a world of "platforms and users", then a football club looks like a two-sided business because it helps bring both sides of users "on board". ${ }^{74}$ On the one hand, "marquee" players will drive up fan base and viewership. ${ }^{75}$ On the other hand, a large fan base and viewership will boost the attractiveness, in both financial and reputational terms, of clubs to players. Instead, if one thinks of the economy as a world of "firms with buyers and sellers", then a football club does not look like a two-sided platform. It is a vertically structured organization that transforms inputs (players) into products (games and entertainment sold in various forms). This simple illustration aids understanding the sheer necessity to clear up a number of ambiguities that have insidiously penetrated the literature on two-sided markets. As R. Bork once wrote, "wrong ideas, repeated often enough, lodge themselves in the culture as well as the law, and they proceed to expand according to their inner logic". ${ }^{76}$ At this juncture, the time may be ripe for rationalization.

\section{Illustrations}

The logical implication of the variance in definitions and concepts used in the literature should be observable through divergences in the qualification of real-life markets as two-sided. This

\footnotetext{
73 Andrea Amelio \& Bruno Jullien, Tying and Freebies in Two-Sided Markets, 30 InT'L J. INDUSTRIAL ORG., Issue 5, 436, 436-46 (2012).

${ }^{74}$ Eisenmann, Parker, G. \& Van Alstyne, supra note 50, at 1.

${ }^{75} I d$.

${ }^{76}$ Bork, supra note 16 , at 420.
} 
section empirically documents this issue. Although authors seem to agree on a core list of twosided markets, for others there are striking discrepancies (1). This section reviews several real life markets under the above definitions, so as to further assess whether they are conducive to distinct qualifications (2).

\section{OVERVIEW OF THE LITERATURE}

By and large, there is a consensus in the literature in relation to a core of markets that can be deemed two-sided. Those are the markets that were initially examined in the seminal two-sided markets papers. They include software (videogame platforms), media (portals, TV and newspapers) and payment card systems. ${ }^{77}$ Similarly, it is relatively undisputed today that matching markets and intermediation services (such as night clubs, social gatherings, etc.) constitute two sided markets. ${ }^{78}$

Besides these classic examples, disagreements have been more pronounced. Summarizing the literature, Fillistrucchi et al. explain for instance that the categorization of supermarkets and airports as two-sided markets has been debated ${ }^{79}$. Our own review of the literature confirms the existence of divisions in the scholarship. Armstrong argues that supermarkets are twosided $^{80}$, whilst Rysman disagrees ${ }^{81}$. Similarly, Eisemann et al. consider that retail electricity markets are evolving in two-sided markets ${ }^{82}$, whilst Rochet and Tirole seem to disagree ${ }^{83}$.

But the most baffling finding of our literature review is that real-life markets are often categorized as multi-sided without any substantiation. In particular, many papers affirm that a given market is two-sided, but provide neither explicit citation of prior art nor proof of verification under any of the three seminal definitions. Instead, papers often make short shrift of this issue, with rote reference to the fact the platform must get all sides on board or that there

\footnotetext{
${ }^{77}$ Rochet \& Tirole, supra note 19, at 992.

${ }^{78}$ Caillaud \& Jullien, supra note 3, at 310.

${ }^{79}$ Filistrucchi et al., supra note 55, at 3.

${ }^{80}$ Armstrong, supra note 20, at 684.

${ }^{81}$ Rysman, supra note 4, at 126.

${ }^{82}$ Eisenmann, Parker \& Van Alstyne, supra note 50, at 3.

${ }^{83}$ Rochet \& Tirole, supra note 21 , at 648.
} 
is a cross-platform externality. In the literature, such showings have been sufficient to presume that the following markets are two-sided: expos and trade fairs, standardized tests, real estate agencies, airports, stock exchanges, credit rating services, academic publishing, ranking websites, conferences, patent pools and industrial standards, etc. ${ }^{84}$ Perhaps the most perplexing example is that given by Rysman, who claims that franchising constitutes a two-sided market. In his view, the "franchisor operates a two-sided market in the sense that it attracts consumers to its brand and franchisees to operate outlets". ${ }^{85}$ This, however, leaves entirely out of account the fact that franchising is a transaction market of the "payment type", where franchisees and consumers conclude side deals. There is therefore a theoretical possibility of a Coasian passthrough. And it cannot be discarded in the abstract. In this case, the characterization of the market as two-sided should ultimately rest upon the extent of this pass-through.

\section{ASSESSMENT}

In the table below, we have attempted to draw a list of possible two-sided markets and to apply to them the three different definitions of two-sided markets discussed previously. ${ }^{86}$ The objective of this exercise is not to reach a prescriptive conclusion on whether a given market is two-sided, but to show that different definitions of the term have a substantial impact on what might be considered as a two-sided market. Although this is a crude assessment, we expect that a more sophisticated analysis would produce similar conclusions.

\begin{tabular}{llll|} 
& $\begin{array}{l}\text { Rochet and Tirole (2006) } \\
\text { (price structure matters } \\
\text { and inability to negotiate } \\
\text { away part or all of the } \\
\text { price allocation (incl. } \\
\text { absence of a seller } \\
\text { monopoly) }\end{array}$ & $\begin{array}{l}\text { Schmalensee and Evans } \\
\text { (2012) (two or more } \\
\text { groups of customers; } \\
\text { need each other; cannot } \\
\text { capture the value of } \\
\text { mutual attraction; rely on } \\
\text { a catalyst) }\end{array}$ & $\begin{array}{l}\text { Rysman (2009) } \\
\text { (definition does not } \\
\text { matter, externality } \\
\text { between groups of } \\
\text { agents that are served } \\
\text { by an intermediary) }\end{array}$ \\
\hline Y & Y & Y & Y \\
Payment systems & Y & Y & Y \\
Operating systems & N & Y & Y \\
Online recruitment & Y & Y & Y \\
Shopping malls & Y & Y & Y \\
Academic journals & Y & Y & Y
\end{tabular}

\footnotetext{
${ }^{84}$ For a list, see Wright, supra note 48 , at 44.

${ }^{85}$ Rysman, supra note 4, at 136.

${ }^{86}$ Rochet \& Tirole, supra note 21, at 664; Evans \& Schmalensee, supra note 2, at 7; Rysman, supra note 4, at 126.
} 
Automobile engines

Airports

Supermarkets

Conferences

Franchising

Collecting societies

Highways

\begin{tabular}{|ccc|}
\hline $\mathrm{N}$ & $\mathrm{N}$ & $\mathrm{Y}$ \\
$\mathrm{N}$ & $\mathrm{Y}$ & $\mathrm{Y}$ \\
$\mathrm{Y}$ & $\mathrm{Y}$ & $\mathrm{Y} / \mathrm{N}$ \\
$\mathrm{Y}$ & $\mathrm{Y}$ & $\mathrm{Y}$ \\
$\mathrm{N}$ & $\mathrm{Y} / \mathrm{N}$ & $\mathrm{Y}$ \\
$\mathrm{Y}$ & $\mathrm{Y}$ & $\mathrm{Y}$ \\
$\mathrm{N}$ & $\mathrm{N}$ & $\mathrm{Y}$ \\
\hline
\end{tabular}

Cells are salmon-colored when the assessment relating to a market's two-sidedness is made in an authored paper. In non-salmon cells we apply the authors' definition of two-sided markets, though there is no reference to these markets in their paper. These assessments should be read with caution. As Rochet and Tirole argue, whether or not a market is two-sided depends on a number of fact-specific questions. For a more detailed explanation of our assessment, see Appendix I to this paper.

This crude exercise confirms that distinct definitions give rise to different qualifications. In particular, the exercise suggests that the Rochet and Tirole definition is more restrictive than the others. In that, it disputes the finding of Filistrucchi et al. who consider that the Rochet and Tirole definition is "broader" than the "transactional remedy" definition offered by Schmalensee and Evans. ${ }^{87}$ Our table also shows that the second and third definitions are very close in terms of how easily markets are reputed to be two sided.

\section{CONCLUSION}

The definitional and conceptual fluctuation of the two-sided markets literature is a normal evolution. It takes root in the testing process inherent in economic research (modification in specifications and settings). It is also influenced by the proclivity of academics to distinguish their research from prior art. ${ }^{88}$ The lack of semantic homogeneity in economic discourse may also be an explanatory factor.

This evolution has a number of paradoxical consequences. On the one hand, as economists keep classifying new types of markets (and re-classifying old ones) as two-sided businesses,

\footnotetext{
${ }^{87}$ Filistrucchi et al., supra note 55, at 7.
}

88 Often, economists use different terms to talk about one and a same issue. Professor Gale summarized this very well: "Economists are skilled at recognizing important issues and relationships and suggesting solutions to problems in an economy. Their approaches to addressing these matters are creative and intriguing. Yet, in the few terms reviewed here, the profession needs to agree on definitions and concepts of technical economic terms". See Gale, J., The Language of Economics (13 Nov. 2003) (unpublished working paper), http://ssrn.com/abstract=468642. 
the early literature retrospectively gets celebrated as a general "theory" ${ }^{89}$ According to the Oxford dictionary, a theory is: "a supposition or a system of ideas intended to explain something, especially one based on general principles independent of the thing to be explained". However, when looking at the wider implications of the two-sided market theory, it is apparent that they cannot be generalized and that they are often not independent from the thing to be explained. On the other hand, as it embraces an ever open-ended scope, the theory loses relevance. When reduced to the notions of markets with indirect network externalities and intermediaries, the theory encompasses a vast number of markets including football clubs, MBA or LL.M programs, gasoline powered engines, and franchising. This may be misguided.

The early literature insisted on the satisfaction of several restrictive conditions, and in particular on the absence of Coasian bargaining and the inability to pass-through the price allocation through side payments between end users. Scholars should not lose sight of this, on pain of weakening the theory. As Tirole himself wrote in his famous IO textbook: "At first sight, even a theorist should regret the very high ratio of theory to evidence in a field which is often lacking in generality and in which practical implications are so crucial". 90

\section{THE THEORY OF TWO-SIDED MARKETS AND ITS RELEVANCE TO US AND EU ANTITRUST POLICY}

The combination of academic enthusiasm and uncertainty surrounding the theory of two-sided markets might give rise to a number of challenges and pitfalls for antitrust agencies, regulatory authorities and courts.

In this section, we seek to illustrate this phenomenon by analyzing a sample of US and EU competition cases where two-sided markets might have been at play. Because two-sided market cases are rarely labeled as such, the cases have been selected on the basis of the broad definition given by Rysman. ${ }^{91}$ All of the cases exhibit the basic trait of market two-sidedness, i.e. cross-

\footnotetext{
${ }^{89}$ Although, the term "theory" might only be used as a shorthand, it is present in a number of papers. See notably Evans \& Schmalensee, supra note 2; Wright, supra note 48; Rochet \& Tirole, supra notes $19 \& 21$.

90 Tirole, supra note 17 , at 3.

${ }^{91}$ Despite its weaknesses (as seen previously), this definition is the best proxy to avoid underinclusiveness in the construction of a representative sample of cases. See Rysman, supra note 4 , at 126.
} 
platform externalities, although - on the basis of publicly available information - we cannot authoritatively affirm that they were genuine two-sided markets.

In this rough sample, we distinguish between two types of cases. Part (A) covers cases where the theory of two-sided markets was avowedly taken into (some) consideration, whilst part (B) covers cases where the theory was not clearly or explicitly taken into account. The latter part covers either cases where authorities were familiar with the theory of two-sided markets but deliberately decided to leave it aside; cases where the authorities ignored the existence and relevance of the theory for the matter to decide; or cases where the authorities applied the theory, but did not say so expressly.

With this section, our ambition is twofold. In cases where the theory was applied, we question whether authorities drew the right (or wrong) implications from it. In cases where the theory was not applied, we question whether two-sided markets were actually involved and whether a two-sided analysis would have brought added value to the resolution of the cases.

\section{A. CASES WHERE THE THEORY WAS TAKEN INTO (SOME) ACCOUNT}

The difficulties faced by competition authorities when applying the theory of two-sided markets

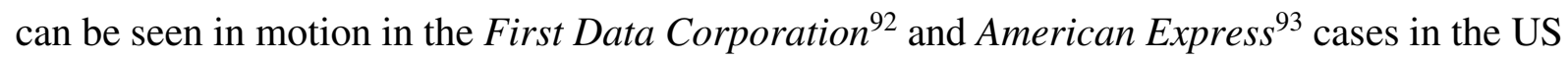
(1) and the Groupement des cartes bancaires ${ }^{94}$ and MasterCard ${ }^{95}$ cases in the EU (2).

All four of these cases concern payment card systems, which are canonical examples of two sided markets. Card systems are generally divided into 3-party and 4-party systems. In a 3party system, a single entity is responsible for the system's issuing and acquiring activities. Issuing refers to the segment where card networks distribute cards to users, while acquiring refers to the other side of the platform, where they attempt to get merchants to accept their

92 United States and Plaintiff States v. First Data Corp. and Concord EFS, Inc., No. 1:03CV02169 (D.D.C., 2003).

${ }^{93}$ United States of America et al. v. American Express Company et al., No. 10-CV-4496 (NGG) (RER), (United States District Court Eastern District of New York, February 19, 2015).

94 Case C-67/13 P, Groupement des cartes bancaires v. Commission, not yet published (September 11, 2014).

${ }^{95}$ Case C-382/12 P, MasterCard and Others v. Commission, not yet published (September 11, 2014). 
cards. American Express is probably the best know 3-party system. In contrast, a 4-party system brings together a number of banks that can operate in both the issuing an acquiring segments. In such systems, cardholder banks (the issuing segment) interact with merchants' banks (the acquiring segment) through payment platforms such as Visa and MasterCard. The ultimate function of the platform is to perform payment transactions between issuing and acquiring banks. In both types of systems, the allocation of the platform's costs among the issuing and acquiring sides of a network can drive card adoption up or down. In this respect, a crucial finding of two-sided markets theory is that it is often optimal to allocate the platform's costs on the acquiring side and to sponsor the issuing side. ${ }^{96}$ This is done seamlessly in a 3party system (the platform can easily adapt the prices it charges to users on both sides). In a 4party system, this is often done by making acquiring banks pay a fee to issuing banks for each transaction (this is usually referred to as an interchange fee).

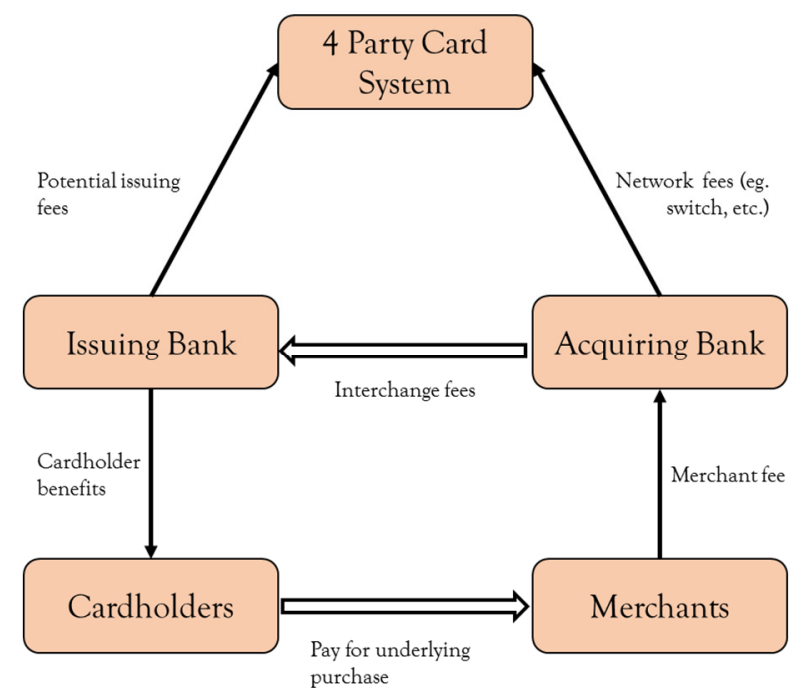

purchase

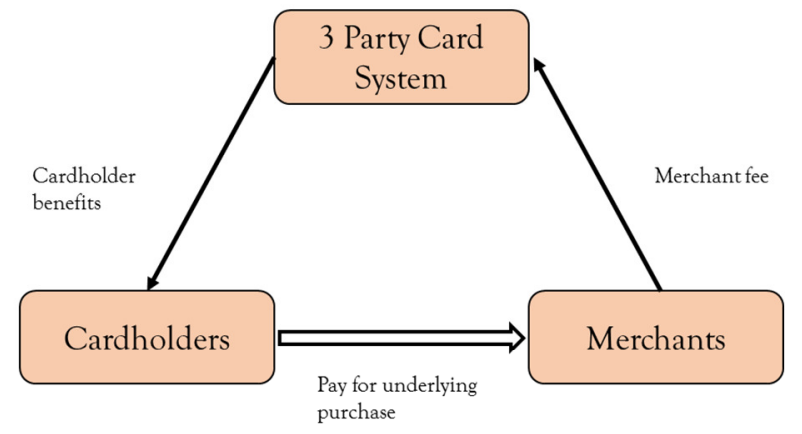

1. US CASES: FirSt DATA CORPORATION AND AMERICAN EXPRESS

\subsection{FIRST DATA CORPORATION}

One area which has drawn much attention from scholars is that of market definition in twosided markets. On both sides of the Atlantic, a prior to measuring market power consists in

${ }^{96}$ Rochet \& Tirole, supra note 19 , at 1013. 
defining relevant markets. ${ }^{97}$ A relevant market comprises all the products (or services) that compete as substitutes. The conventional method for the definition of relevant markets is to apply the "SSNIP" test (sometimes referred to as the "hypothetical monopolist" test). ${ }^{98}$ Technically speaking, the SSNIP test gauges the cross-price elasticity of demand. It tests whether demand will switch to other products (or services) when a Small but Significant Nontransitory Increase in Price - typically in the range of 5 to $10 \%$ - is applied to the product under consideration. To take a classic example, if demand for Coca-Cola shifts to Pepsi when Coke's price increases by $10 \%$, then there is a relevant market for cola drinks that comprises both CocaCola and Pepsi. The underlying theoretical question is whether the price rise is profitable despite the loss in demand. If it is profitable, then alternative sources of supply do not constrain the "hypothetical monopolist" and the candidate group of products constitutes a relevant market of its own. If it is unprofitable, the products to which demand switches must be deemed to constrain the supplier, and to form part of the relevant market.

A number of authors have argued that in two-sided markets the SSNIP test might require significant tweaking. ${ }^{99}$ In a nutshell, they suspect that the SSNIP test does not correctly capture cross-platform externalities. Losing demand on one side of the market can have an impact on the number of users present on the other side, making the platform less profitable. Those

97 This analytical method owes much to Posner \& Landes' seminal article on market power and market definition in antitrust cases. See Richard A. Posner \& William M. Landes, Market Power in Antitrust Cases, 94 HARV. L. REV., 937, 937-96 (1980).

${ }^{98}$ The use of the SSNIP test is notably mentioned in the US merger guidelines and the European guidelines on market definition. See US Department of Justice and Federal Trade Commission, Horizontal Merger Guidelines, S. 4.1.1. (August 19, 2010), https://www.ftc.gov/sites/default/files/attachments/merger-review/100819hmg.pdf. See EU Commission, Commission Notice on the definition of relevant market for the purposes of Community competition law, OJ C 372, 5, §15-19 (December 9, 1997).

${ }^{99}$ See notably Eric Emch, E. \& T. Scott Thompson, Market Definition and Market Power in Payment Card Networks (EAG Discussions Papers, No. 200609, Department of Justice, Antitrust Division. 2006); Renata B. Hesse \& Joshua H. Soven, Defining Relevant Product Markets in Electronic Payment Network Antitrust Cases, 73 ANTITRUST L.J., No. 3, 709-738 (2006); David S. Evans \& Michael Noel, The Analysis of Mergers That Involve Multisided Platform Businesses, (Working Paper, 2008), http://econweb.ucsd.edu/ mdnoel/research/NOEL_twosidedmergers.pdf; Lapo Filistrucchi, Damien Geradin, Eric van Damme \& Pauline Affeldt, Market Definition in Two-Sided Markets: Theory and Practice (Tilburg Law School Research Paper, No. 09/2013, 2013), http://ssrn.com/abstract=2240850. 
indirect network externalities should be brought into the picture when the SSNIP test is applied in two-sided markets. Such externalities may turn a profitable SSNIP on a single side into an unprofitable SSNIP when both sides are taken into account.

The application of the SSNIP test in two-sided markets was one of the issues raised by the DoJ and the parties in the United States v. First Data Corp District Court case. ${ }^{100}$ The case concerned a merger between First Data Corporation and Concord, the owners of two of the three biggest PIN debit networks in the United States. PIN debit is an electronic payment method that entitles shoppers to pay merchants with cards, upon entry of a personal identification number that authorizes the issuing bank to debit funds from the cardholder's bank account. ${ }^{101}$ Like credit cards, these networks are a typical example of a two-sided market. Shoppers value PIN debit cards that give them access to more merchants, while merchants value PIN debit brands that give them access to more customers. ${ }^{102}$

United States v. First Data Corp provides a good illustration of the practical intricacies faced by authorities when implementing the SSNIP test in two-sided markets. Four of them are particularly noteworthy.

First, should a single SSNIP test be applied to both sides of the market, or should a separate test be applied to each side? ${ }^{103}$ In the First Data case, the DoJ looked at both sides of PIN networks separately and only applied the SSNIP test to the merchant side (it is on this side that ${ }^{100}$ United States and Plaintiff States v. First Data Corp. and Concord EFS, Inc., No.
1:03CV02169 (D.D.C., 2003).

${ }^{101}$ See OECD Policy Roundtables, Two-Sided Markets, $36 \quad$ (2009), http://www.oecd.org/daf/competition/44445730.pdf (referring to the US First Data Corp. case).

102 That being said, PIN debit networks with fewer merchants can attract financial institutions through various other means, such as more competitive fees, network reliability and speed. In addition, potential cross-network externalities are mitigated by the fact that most financial institutions conclude deals with the main card networks and issue cards that are compatible with multiple networks. On the merchant side, the most important parameter of competition is not a PIN network's size, but the level of its fees. This suggests that network externalities might not be particularly significant, especially from the merchant's point of view.

${ }^{103}$ In practice, this distinction implies that authorities will either define a single platform market or two relevant markets on both sides of the platform. This issue is akin to that of "relevant submarkets", which was notably addressed in the Brown Shoe case, as early as 1962. See Brown Shoe Co., Inc. v. United States, 370 U.S. 294 (1962). 
anticompetitive effects were deemed most likely) ${ }^{104}$. Whether this was the right decision is debatable. Some economists argue that a single "platform" market should be defined when users on both sides of the platform conclude tangible transactions ${ }^{105}$ (i.e. a financial transfer in exchange for a good or service) which is the case of most card networks and not the case of most advertising platforms. In so-called "transaction" markets, losing users on one side will equally and automatically affect the other side. ${ }^{106}$ In non-transaction markets, this relation does not necessarily hold true. For instance, users of a search engine are probably insensitive to a loss in advertisers on the other side of the platform.

Other economists argue that both sides of a platform should be looked at separately. ${ }^{107}$ They contend that a dominant card network might decide to exercise its market power by raising prices on a single side of the platform. It would thus be preferable to apply the SSNIP test separately on both sides, in order to identify the competitive constraints that are present on each one.

Choosing one method or the other is not without consequences. Defining a single platform market will normally imply a larger price increase. Imagine a platform which charges $20 €$ per transaction, split equally between users on both sides (10/10). A 10\% platform SSNIP would look at consumer switching when the platform charges a total of $22 €$ per transaction. In contrast, a single side SSNIP would look at consumer switching when a 10\% increase is applied to one side. The total price would thus be $21 €$. The literature provides little guidance as to which of these two routes is the most appropriate. What is clear, however, is that larger increases generally lead to larger relevant markets, as consumer switching becomes more prevalent.

Second, regardless of the approach followed, authorities will have to decide how to allocate the $10 \%$ price increase among different groups of users. This is no easy choice. Returning to our

\footnotetext{
${ }^{104}$ Plaintiff's Pretrial Brief, United States and Plaintiff States v. First Data Corp. and Concord EFS, Inc., No. 1:03CV02169, Section V. A. (D.D.C., 2003).

${ }^{105}$ See notably Emch \& Thompson, supra note 99, at 16; Evans \& Noel, supra note 99, at 16; Filistrucchi et al., supra note 99, at 10.

${ }^{106}$ Evans and Noel notably refer to services that are sold in fixed proportions on both sides of the platform. Evans \& Noel, supra note 99, at 16.

${ }^{107}$ See notably Hesse \& Soven, supra note 99, at 727.
} 
example, the $10 \%$ increase can be allocated in a range of different ways (for instance, 12/10; $11 / 11 ; 10 / 12)$. Authorities might assume that because the platform was previously charging $10 €$ to both sides, the increase should be spread equally (11/11). On the other hand, they may also decide to change the price allocation. A hypothetical monopolist platform might thus charge $12 €$ to one side and $10 €$ to the other. The pros and cons of each option remain unclear and economists disagree on the appropriate method. Some posit that the hypothetical monopolist should be allowed to adjust the price structure ${ }^{108}$, while others argue it should not ${ }^{109}$. In the First Data case, the DoJ argued that a hypothetical monopolist would raise prices by 5$10 \%$ on the acquiring banks side (and hence to merchants), and held the price to issuing banks fixed. ${ }^{110}$

Market definition is also complicated when one side receives the platform's services free of charge. Adjusting our example slightly, a platform may charge the entire $20 €$ transaction fee on one side of the market only. In such cases, should the SSNIP only be applied to the "money" side? And what if the price increase were also applied, in full or part, to subsidized users? $10 \%$ or less of zero is still zero. A symbolic fee might have to be set, but this could have dramatic effects. Imagine if Google were ever to charge users 1cent per search; users would surely flee in droves.

Of course, a possible solution to this logjam is to consider that Google charges an implicit price on users, which consists in extracting personal data from them. But it is unclear how to operationally simulate the effects on demand of a "small but significant increase in data extraction". Similarly, one may consider that Google, as a hypothetical monopolist, will instead

\footnotetext{
${ }^{108}$ See Emch \& Thompson, supra note 99, at 27 (The authors argue that a monopolist should be allowed to adjust the price structure through interchange fees); Lapo Filistrucchi, A SSNIP Test for Two-Sided Markets: The Case of Media (NET Institute Working Paper No. 08-34, at 11, 2008), http://papers.ssrn.com/sol3/papers.cfm?abstract id=1287442; Filistrucchi et al., supra note 99, at 37 (the authors argue that even when a single-sided SSNIP is conducted, the platform should be allowed to adjust the price structure. Though is not quite clear how this should be done in a single-sided context.

${ }^{109}$ See Evans \& Noel, supra note 99, at 16.

${ }^{110}$ Plaintiff's Pretrial Brief, United States and Plaintiff States v. First Data Corp. and Concord EFS, Inc., No. 1:03CV02169, Section V. B. (D.D.C., 2003).
} 
degrade the quality of the content offered to its users. But applying a "small but significant decrease in content quality" test would certainly prove a daunting task.

A third question is how to capture the fact that SSNIP increases can affect demand on both sides of a platform? A price increase will directly decrease demand on the side of the platform where it is applied. However, in two-sided markets, this price increase may also decrease demand on the other side of the platform if there are positive network externalities (female and male clients in night clubs) and increase demand on the other side if there are negative network externalities (advertisement on TV). In turn, this reduction can further affect the users to whom the price was initially applied, and so forth. The idea that authorities should take these externalities into account is relatively uncontroversial. In United States v. First Data Corp, the DoJ appears to have taken those externalities into some account. ${ }^{111}$ But due to a lack of publicly available information, it is unclear how this was done in practice. And beyond the model of Evans and Noel $^{112}$, the research on this issue remains embryonic.

A fourth and final question concerns the baseline upon which the SSNIP test is calculated. When possible, the SSNIP test should be based on a supplier's (i.e. the platform, in two-sided markets) contribution to the final price. ${ }^{113}$ For example, in the case of firms that transport gas through pipelines, the SSNIP paid by gas purchasers should be based only on the price paid for transport, rather than on the basis of the total price which includes gas and transport; in the case of supermarkets, the SSNIP should be applied on the basis of a retailer's' margins, rather than on the basis of the total retail price; and in the case of e-booking services, the SSNIP increase should be applied to the commission charged by the platform, instead of the final price charged to travelers; etc.

In real-life cases, this baseline is often difficult to identify. The First Data case illustrates this very well. Merchants' banks paid two separate transaction fees to the card network: a switch fee and an interchange fee. The parties to the merger argued that only the switch fee should be increased because the interchange fee did not accrue to the PIN debit platform, but was

${ }^{111}$ See Hesse \& Soven, supra note 99, at 726.

${ }^{112}$ See Evans \& Noel, supra note 98.

113 See US Department of Justice and Federal Trade Commission, Horizontal Merger Guidelines, S. 4.1.2., Example 8 (August 19, 2010), https://www.ftc.gov/sites/default/files/attachments/merger-review/100819hmg.pdf. 
ultimately transferred to financial institutions. ${ }^{114}$ They thus contended that a PIN debit monopolist would use its market power by increasing the switch fee, not the interchange fee. The DoJ countered that the total fee paid by merchant banks was the relevant benchmark because merchant demand depended on the sum of these two fees. ${ }^{115}$ Again, choosing one option or the other can have an important impact on the results of a SSNIP. Notably, the interchange fee was much larger than the switch fee. As a result, the DoJ's proposed approach led to a much larger SSNIP price increase than a $5 \%$ to $10 \%$ increase in the total switch fees.

To summarize, most economists agree on the high level idea that the SSNIP test should be adjusted in multi-sided environments. But there is much less consensus on the practicalities of SSNIP analysis in such markets. ${ }^{116}$ In the First Data case, there was a reasonable alternative to almost every decision made by the DoJ on the SSNIP test. There is thus some way to go before the SSNIP test can be applied to two-sided markets with any consistency.

\subsection{AMERICAN EXPRESS}

The American Express ${ }^{117}$ case concerned rules imposed by American Express (hereafter "Amex"), one of the largest credit card networks in the US. The rules (hereafter "NDPs") prevented merchants that deal with Amex from "steering" cardholders towards cheaper card networks. Amex's NDPs imposed what can be thought of as a rule of card neutrality: if a merchant accepts American Express - which might attract shoppers - it cannot then encourage shoppers to use a competing card network that charges lower merchant fees. The plaintiffs (the United States and a number of state attorneys general) contended that the NDPs had suppressed price competition among card networks for merchants. They argued that if merchants cannot steer shoppers towards competing card networks which charge lower fees, then card networks

${ }^{114}$ Plaintiff United States' Reply to Defendants' Pretrial Brief Pretrial brief, United States and Plaintiff States v. First Data Corp. and Concord EFS, Inc., No. 1:03CV02169, Section II. (D.D.C., 2003).

${ }^{115}$ See Hesse \& Soven, supra note 79, at 729.

${ }^{116}$ Some economists have, however, optimistically referred to "principles of market definition in two-sided platform". See James D. Ratliff and Daniel L. Rubinfeld, Is There a Market for Organic Search Engine Results and Can Their Manipulation Give Rise to Antitrust Liability?, 10 J. COMPETITION L. AND ECON., Issue 3, 517, 518 (2014).

${ }^{117}$ United States of America et al. v. American Express Company et al., No. 10-CV-4496 (NGG) (RER), (United States District Court Eastern District of New York, February 19, 2015). 
have no incentive to set merchant fees below the monopoly price. Amex rejected these claims and responded that the NDPs provided a premium user experience to Amex cardholders ${ }^{118}$ and prevented rival card networks from free-riding on Amex's promotional investments which attract cardholders to points of sale.

Siding with the plaintiffs, the Court considered that, in a world with NDPs, cardholders decide which payment card to use without any interference from merchants. Cardholders hold the key and will thus choose a payment method based on their preferences, notably the rewards they receive, rather than merchants' costs. As a result, card networks have no incentive to offer merchants lower fees than their rivals. The Court argued that this was not just bad for merchants, but also for all shoppers that do not use a card, but pay cash ${ }^{119}$. This is because merchants can pass on those inflated costs to cash shoppers through increased retail prices. Cash shoppers thus indirectly pay for card transactions without deriving any benefits from them. ${ }^{120}$

The Amex case is mired with references to two-sided markets. For example, the background section of the ruling contains a lengthy introduction to the theory of two-sided markets. But those references were ultimately planted there to set the stage for the case, and nothing more. In contrast, the theory played almost no role in the resolution of the case's thorniest issues. This can be observed at three levels.

\footnotetext{
${ }^{118}$ Premium users might not want to be hassled by merchants' efforts to reduce payment costs.

119 The Court goes one step further and argues that even cardholders end up on the losing end because merchants will increase prices to a higher tune than the additional rewards received by cardholders. United States of America et al. v. American Express Company et al., No. 10-CV4496 (NGG) (RER), at 114 (United States District Court Eastern District of New York, February 19, 2015).
}

${ }^{120} I d$., at 99. The Court also mentions this effect with regard to cash shoppers. Concerning this externality that is imposed on cash shoppers, see Denis W. Carlton, Externalities in Payment Card Networks: Theory and Evidence: A Commentary (Conference, Federal Reserve Bank of Kansas City, The Changing Retail Payments Landscape: What Role for Central Banks?, 126 , 2009), http://faculty.chicagobooth.edu/dennis.carlton/research/pdfs/ExternalitiesPaymentCardNetwor ksTheoryEvidenceCommentary.pdf. Carlton notably refers to a seminal paper by Baxter. See William F. Baxter, Bank Interchange of Transactional Paper: Legal and Economic Perspectives, 26 J. L. \& Econ., Issue 3, 541-88 (1983). 
First, the Court concluded that Amex's NDPs restricted competition because they removed card networks' incentive to compete on prices ${ }^{121}$. In contrast, the two-sided markets literature suggests that even when steering is prohibited card networks have strong incentives to offer competitive prices to merchants. Each merchant must weigh the costs and benefits of accepting a network's cards. In that regard, it is clear that the fees that a payment network charges depend heavily on whether it can bring exclusive users to the table. If the network has no exclusive users (i.e. if all its users multi-home), it will have to charge lower fees than its competitors in order to be accepted by merchants. ${ }^{122}$ In contrast, if the network has only exclusive users, it will be able to charge merchants the monopoly price (this is often referred to as a competitive bottleneck). ${ }^{123}$ Merchant fees will thus reflect the benefits brought by exclusive users and the potential losses from multi-homing users (who would otherwise use a card with lower merchant fees). In short, some form of price competition will persist despite the presence of NDPs. This is not to say that NDPs cannot conceivably lead to increased prices, but that their effect on prices is much more ambiguous than the Court's ruling might suggest.

A second question is whether a restriction of price competition for merchants reduces social welfare. In that regard, the Court simply reported that merchant fees had increased in the period that followed the introduction of anti-steering provisions by Amex and other card networks ${ }^{124}$. Even if one were to assume that this increase was caused by Amex's introduction of NDPs, such a finding is in itself insufficient to derive that NDPs are anticompetitive. As we note

${ }^{121}$ United States of America et al. v. American Express Company et al., No. 10-CV-4496 (NGG) (RER), at 100 (United States District Court Eastern District of New York, February 19, 2015).

122 Rochet \& Tirole, supra note 19, at 993 and 1013. Moreover, one should not forget that NDPs are not a foregone conclusion. Assuming that NDPs actually cost merchants revenue, then card networks have to forgo some amount of card fees to induce merchants to agree to NDPs.

123 Armstrong, supra note 20, at 677. Note that, even in these situations, a card network's market power may be transient. Indeed, one should not assume that single-homing is immutable. Seeing that their competitor can earn monopoly profits thanks to an exclusive group of cardholders should encourage rival card networks to compete for these same users. The rival networks can offer cardholders identical rewards and lower fees to merchants, by transferring a larger percentage of merchant fees across the platform.

${ }^{124}$ United States of America et al. v. American Express Company et al., No. 10-CV-4496 (NGG) (RER), at 111 (United States District Court Eastern District of New York, February 19, 2015). 
further down ${ }^{125}$, a price increase on one side of a platform can increase overall output. For instance, the higher fees paid by merchants might be outweighed by increased card use, which boosts sales. The "card use externality" theory of harm put forward by the Court is thus only one side of the coin. Clearly, increased merchant fees have the potential to harm consumers, including cardholders. But they also have the potential to promote card use and efficient shopping. Which of these effects dominates invariably hinges upon case-specific assessments. In that regard, the Court's contention ${ }^{126}$ that the merchant fee increases were only partially passed-on to cardholders is insufficient to conclude that output decreased. Indeed, the twosided markets literature does not exclude that an increase to a platform's price level can be offset by changes to its price structure.

A third question is that of market definition, for the Amex case seems to both follow and depart from First Data. On the one hand, the Amex case is a replay of the First Data single-sided SSNIP approach, ${ }^{127}$ which consisted in increasing the price asymmetrically (i.e. the price paid by cardholders was held constant) ${ }^{128}$ and taking cross-platform feedback effects into account ${ }^{129}$. On the other hand, the Amex Court departed from First Data with regards to the fees upon which the SSNIP test was applied. Unlike in First Data, where the SSNIP was applied to the entire fee level paid by merchants, two different SSNIP tests were calculated. First, a 10\% price increase was applied solely to the switch fees paid by merchants ${ }^{130}$. Second, a $5 \%$ increase was applied to the entire merchant fees ${ }^{131}$. In both cases, the Court found a profitable SSNIP, thereby suggesting market power. Interestingly, the Court also sought to buttress its SSNIP analysis with qualitative market information.

\section{EU CASES: GROUPEMENT DES CARTES BANCAIRES AND MASTERCARD}

\footnotetext{
${ }^{125}$ See section III.A.3

${ }^{126} I d$., at 112 .

${ }^{127} I d$., at 47.

${ }^{128} I d$., at 48 .

${ }^{129} I d$.

${ }^{130} I d$.

${ }^{131} I d$.
} 


\subsection{GROUPEMENT DES CARTES BANCAIRES}

In Groupement des cartes bancaires ${ }^{132}$, a trade association of French banks in charge of a payment cards infrastructure had introduced several measures aimed at achieving a certain balance between its members' acquisition and issuance activities. In particular, the association was seeking to prevent some of the member banks from free-riding on others by only operating in the issuing segment, which was more lucrative than the acquisition segment. The association had accordingly established a complex fee system which penalized banks with a heavy issuing profile or with low acquisition activities. ${ }^{133}$

The compatibility of those measures with the law on anticompetitive coordination was brought to the attention of the European Commission and the General Court ("GC", the jurisdiction which reviews, in first instance, appeals against the Commission's decisions). Much of the case hinged upon the alleged multi-sidedness of the card system, and its implications for the antitrust analysis.

Both the Commission and the GC acknowledged the existence of externalities between the acquiring and issuing sides of the card system. However, they then nevertheless took the view that the issuing side of the platform was the only relevant market in which competition was to be scrutinized. ${ }^{134}$ Proceeding on this logic, both the Commission and the General Court were drawn to the inevitable conclusion that the association's measures were presumably anticompetitive and had to be dealt with under a quasi per se prohibition rule. This is not

132 Case C-67/13 P, Groupement des cartes bancaires v. Commission, not yet published (September 11, 2014).

${ }^{133} I d$., at $\S 4$. Three measures were a stake: first, a fee (called the MERFA) levied on banks that were heavy issuers and destined to finance the acquisition activities of the system; second, a membership fee and fees linked to the issuance of new credit cards; finally, a fee per card issued imposed upon members that had not been active during a given time period (in effect, this fee prevented banks from rapidly entering the issuing segment of the system).

${ }^{134}$ See Case COMP/D1/38606, Groupement des cartes bancaires “ $C B$ ”, notably $§ 180$ (October 17, 2007). The Commission recognized the existence of three separate markets: the issuing market, the acquiring market and the market for payment systems. In doing so, it avoided much of the debate surrounding market definition questions in two-sided markets. See also Case T491/07, Groupement des cartes bancaires v. Commission, ECR 2012 -00000, §105 (November 29, 2012). 
surprising. Looking only at the issuing side of the market, the impugned measures looked like garden variety naked restraints.

When the case reached the Court of Justice ("the Court") on further appeal, a more holistic approach was followed. ${ }^{135}$ Indeed, the Court found that the General Court had insufficiently taken into account of the economic context of the disputed fees. Instead, the General Court should have looked at both sides of the payment system. ${ }^{136} \mathrm{Had}$ it done so, it would have realized that the fees sought to achieve a balance between the acquiring and issuing activities of the association, and that they were not "by their very nature" harmful to competition. ${ }^{137}$ In turn, the Court suggested that a "rule of reason" approach might have been more appropriate. ${ }^{138}$

The Court judgment in Groupement des cartes bancaires was celebrated in the EU antitrust community. Several antitrust scholars and practitioners were prompt to read in it a blueprint for the introduction of two-sided markets theory in EU competition law. ${ }^{139}$ However, any such expectations may have been dampened by the concomitant ruling in MasterCard, which was handed down the same day (and by the same judges).

\subsection{MASTERCARD}

The Master $\operatorname{Card}^{140}$ case confronted the Court with the next, alternative, question: how to apply a "rule of reason" type analysis in two-sided markets? To ease understanding, the reader will recall that in the European context, competition agencies and courts that apply the rule of reason

135 The EU's equivalent to the Supreme Court.

${ }^{136}$ See Case C-67/13 P, Groupement des cartes bancaires v. Commission, not yet published, at $\S 76,77,78 \& 79$ (September 11, 2014).

${ }^{137} I d$. at $\$ 78$.

${ }^{138}$ In other words, restrictions of competition on one side of a two-sided market could not be folded in the "object" box, if there was a prima facie justification for them pertaining to the other side of the market. However, this did not mean that they are immune of prosecution under the "effects" analysis.

${ }^{139}$ See notably Frederic Pradelles \& Andreas Scordamaglia-Tousis, The Two Sides of the Cartes Bancaires Ruling: Assessment of the Two-Sided Nature of Card Payment Systems Under Article 101(1) TFEU and Full Judicial Scrutiny of Underlying Economic Analysis, 10 COMPETITION POL'Y INT'L, No. 2, 139, 151 (2014).

${ }^{140}$ Case C-382/12 P, MasterCard and Others v. Commission, not yet published (September 11, 2014). 
must first review anticompetitive effects under article 101(1) TFEU and then consider redeeming pro-competitive justifications under article 101(3) TFEU. As will be seen below, the Court's approach strays from Groupement des cartes bancaires on both counts.

MasterCard was about the interchange fees levied by banks that participated to the MasterCard payment system. To summarize, once a card payment is processed in a merchant's store, the MasterCard system requires the acquiring bank (the merchant's bank) to pay a fee (normally smaller than the transaction fee) to the issuing bank (the cardholder's bank). This is called an interchange fee. As previously explained, this allows issuing banks to subsidize the use of cards by consumers.

In MasterCard, both the Commission and the General Court had displayed concern that MasterCard - which operated as a trade association - was unlawfully "fixing" these multilateral interchange fees (hereafter, "MIFs"). The theory of harm advanced in support of the case was that since the multilateral fees served as a basis for the calculation of the charges imposed by acquiring banks on merchants (hereafter, "MSCs"), any coordination on their setting risked inflating merchants' costs.

On final appeal, the Court of Justice confirmed the Commission's and the GC's theory of anticompetitive effects. ${ }^{141}$ Like the General Court ${ }^{142}$, it underscored the adverse distributional effect of the MIFs. In the Court's view, the MIFs were problematic because they reduced "the possibility of prices [for merchants] dropping below a certain threshold". ${ }^{143}$ By imposing a higher fee on the acquiring banks, the MIFs inflated the base for the calculation of the MSC subsequently charged by acquiring banks to merchants. ${ }^{144}$ With this, the mechanism placed a

${ }^{141} I d ., \S 183$.

${ }^{142}$ See Case T-111/08, MasterCard and Others v. Commission, ECR 2012 -00000, §143, 163 \&164 (May 24, 2012).

${ }^{143}$ Case C-382/12 P, MasterCard and Others v. Commission, not yet published, at $\S 193$ (September 11, 2014).

${ }^{144} I d$., at $\S 193 \& 195$. 
lower limit on the MSC that in turn led to a transfer of surplus from merchants to acquiring banks. $^{145}$

In contrast, the Court made short shrift of the MIFs' potential output effects, which is the terrain where two-sided markets theory has arguably the most to offer to antitrust analysis. Nowhere does the judgment consider whether the MIFs led to a reduction in card payments. Neither does the judgment discuss whether shifting costs from one side (issuers) of the market to the other (acquirers) could increase output on all sides of the market. ${ }^{146}$

The judgment's lack of interest in output issues is all the more remarkable, given the contemporaneous judgment in Groupement des cartes bancaires. In the case of payment systems, any antitrust observer would have instinctively expected the Court to consider the MIFs' output effects. But framing the case in output terms would have brought to the antitrust debate a boatload of additional complexities. The Court may thus have been reluctant to expend more resources into the resolution of what could otherwise be framed as a clear-cut horizontal coordination case.

The complex implications of a two-sided markets analysis can be best understood with a short numerical example. Let us imagine two different states of the world: one where merchant fees are inflated by MIFs, and another where there are no MIFs. We could further imagine that in a world with MIFs, merchants pay MSCs of $2 €$ per transaction and consumers nothing, whereas in a world without MIFs both merchants and consumers pay $1 €$ per transaction. If their demand is highly elastic, consumers will use their cards far less often when they are charged $1 €$. One could thus imagine a situation where 500 consumers are willing to use their card for $0 €$ and where 100 consumers are willing to use their cards for $1 €$. At the other end of the platform, merchant's demand for card transactions is less elastic: 500 merchants are willing to conclude transactions at $2 €$ per transaction and only 600 merchants might be willing to conclude

${ }^{145} \mathrm{Up}$ to the point where the MSC is so high that merchants refuse to pay (their reserve price). This point is nicely illustrated in the General Court's judgment. Which in more convoluted terms essentially argues that the with the MIF there is both a lower bound to the fee that banks can charge - they do not want to operate at a loss - and an upper bound because they cannot charge too many merchants more than their reserve without losing profits. See Case T-111/08, MasterCard and Others v. Commission, ECR 2012 -00000, at $\$ 158$ (May 24, 2012).

146 The fact that the price structure might affect overall output is one of the key findings of the theory of two-sided markets. See notably Rochet \& Tirole, supra note 21, at 665. See also Evans \& Schmalensee, supra note 2, at 12. 
transactions at $1 €$. Assuming that both merchants and consumers only conclude a single transaction, the two states of the world give the following results. In a world with shared fees (no MIFs), 600 merchants would like to conclude card transactions, but only 100 have that possibility. In short, merchants are rationed: in this world there are simply not enough consumers to satisfy the merchants (and cover their investments into cards systems). Only 100 card transactions are made. In the second world, 600 merchants are willing to conclude card transactions, as are 500 consumers. As a result, there are 500 card transactions. Compared to the first state of the world, it is true that 100 merchants have each lost $1 €$ in consumer surplus. But on the other hand, 400 extra merchants and 400 extra consumers can now conclude card transactions.

In this hypothetical example, merchants are better off paying more because they are no longer rationed $^{147}$. Increased MIFs may thus lead to Pareto improvements. This, in turn, would militate in favor of a regime of antitrust exoneration.

But this will not always be the case. For a start, higher MIFs do not necessarily increase a payment system's output. For example, the extra sums paid by merchants might be absorbed by the card payment platform and/or only marginally transferred to the issuing side. Moreover, consumers' elasticity might not be as high as in our example. Even if it is passed on to consumers, a higher MIF might not increase output if the demand of consumers demand is less elastic than that of merchants. Furthermore, platforms can also charge merchants well beyond the point where consumers' adoption of the platform is increased. ${ }^{148}$ Last, empirical literature suggests that interchange fees and their suppression have little effect on consumer welfare. ${ }^{149}$

${ }^{147}$ The example also shows the importance of the Coase theorem. If merchants could pay cardholders to use their cards, the output effect would disappear.

${ }^{148}$ Hélène Bourguignon, Renato D. Gomes \& Jean Tirole, Shrouded Transaction Costs (CEPR Discussion Paper, No. DP10171, 2014), http://ssrn.com/abstract=2503401; Özlem BedreDefolie \& Emilio Calvano, Pricing Payment Cards 13-14 (European Central Bank, Working Paper Series, No. 1139, December 2009), https://www.ecb.europa.eu/pub/pdf/scpwps/ecbwp1139.pdf?06e92331e616420341a38add0b0 18 aa7.

${ }^{149}$ Carlton, supra note 120 , at 129. 
More importantly, as discussed previously in relation to the Amex case, MIFs may impose negative externalities on cash shoppers. This occurs due to the combination of merchant fees and of the no-surcharge rule which is commonly applied in the payment system industry. Under the no-surcharge rule, merchants must charge the same price to all customers regardless of their payment method. With this background, merchants may thus have incentives to pass on the cost of the merchant fee to all shoppers indistinctly, through increased retail prices. Both card and cash shoppers will thus bear the costs generated by card payments. ${ }^{150}$ Moreover, the MIFs may generate an even higher adverse effect on cash shoppers, because cardholders are often subsidized by the issuing bank. The latter may thus bear less of the card system's costs than cash shoppers, though the magnitude of this effect remains ambiguous.

Finally, a number of economists have proposed ${ }^{151}$ to introduce a so-called "tourist test" to determine whether the level of interchange fees is excessive ${ }^{152}$. The "tourist test" asks whether, given the choice, a merchant would choose to turn down a payment card in favor of cash payments. To pass the test, the net benefits from a card payment, for the merchant, musk exceed the level of the merchant fee. Despite all its merits, the test remains an imperfect proxy. It notably assumes that the relevant consumers are able and willing to pay with cash, which is a crude assumption. It also ignores the fact that accepting a card can draw consumers to the merchant shop and boost sales. Last, it discounts potential negative externalities that stem from cash payments, such as tax fraud. ${ }^{153}$

${ }^{150}$ Baxter, supra note 120.

151 Jean-Charles Rochet \& Jean Tirole, Must-Take Cards: Merchant Discounts and Avoided Costs, 9 J. Eur. ECON. Assoc., No. 3, 462-95 (2011).

152 The test is now widely applied by the European Commission. See European Commission DG Competition, Survey on Merchants' Costs of Processing Card Payments, at 68 (March 2015), http://ec.europa.eu/competition/sectors/financial_services/dgcomp_final_report_en.pdf.

${ }^{153}$ For better or for worse, the tourist test has widely been accepted as a benchmark to assess interchange fees, and some have argued that interchange fees which pass the test should be presumed to fill the conditions of article 101(3) TFEU. See European Commission DG Competition, Antitrust: Commissioner Kroes notes MasterCard's decision to cut cross-border Multilateral Interchange Fees (MIFs) and to repeal recent scheme fee increases - frequently asked questions (April 1, 2009), http://europa.eu/rapid/press-release_MEMO-09143 en.htm?locale=en. 
No matter, none of those nuanced considerations trickled into the MasterCard judgment. The Court turned a blind eye to two-sided markets theory. It concluded that the MIFs exerted anticompetitive effects on microscopic distributional grounds, by finding that merchants were harmed through inflated costs. Perhaps, one reason for the Court's disinterest is that it is understandably - reluctant to make comparisons across diverse groups of users. After all, why favor some economic agents on one side - cardholders - at the expense of economic agents on the other side - merchants? However, this fails to capture that the positive effects of MIFs might ultimately revert back to the same group of users that was allegedly harmed, i.e. merchants, through an increase in the overall number of card transactions, and in turn an expansion of total economic output (it has indeed been suggested that the use of payment cards can have a positive impact on overall spending ${ }^{154}$ ). In short, the Court failed to grasp that MIFs might potentially be used to subsidize card adoption and translate into more card transactions for merchants and shoppers alike. Although this virtuous effect is far from certain, one might regret that is was not more central to the ruling.

At some junctures of the judgment, however, the two sided markets theory is given some currency. In particular, the review of the pro-competitive justifications advanced by the parties led the Court to discuss the efficiency benefits of MIFs. In their appeals, the parties argued that the MIFs fulfilled the first condition set out at Article 101(3) TFEU which talks of "improving the production or distribution of goods or to promoting technical or economic progress". ${ }^{155}$ In their view, this was the case because the MIFs sponsored card adoption and thus benefited to cardholders. ${ }^{156}$ The Court took a different tack. It held that when customers on both sides of a two-sided market are not substantially the same, at least some of the benefits that stem from anticompetitive conduct must accrue to those within the relevant market. ${ }^{157}$ Accordingly, because the relevant market was the acquiring side of the platform, some of the MIFs' benefits

\footnotetext{
${ }^{154}$ See notably Mark Zandi, The Impact of Electronic Payments on Economic Growth (February 2013), http://usa.visa.com/download/corporate/_media/moodys-economy-white-paper-feb2013.pdf.

${ }^{155}$ See Article 101(3) TFEU and Case C-382/12 P, MasterCard and Others v. Commission, not yet published, at $\$ 230 \& 234$ (September 11, 2014).

${ }^{156}$ Id., at§228 \& 243

${ }^{157} I d$., at $§ 242$.
} 
had to fall upon merchants and not just upon cardholders. The Court in turn observed that the parties had not challenged the General Court's conclusion that merchants did not benefit from the MIFs. ${ }^{158}$ This was therefore the end of the story. ${ }^{159}$ As has already been mentioned, however, it is not a logical imperative that higher prices necessarily harm merchants. With this in mind, one can only wonder what might have happened if the parties had argued that merchants benefited from the MIFs through increased output.

\section{SUMMATION}

So far, our case review triggers the following observations. First, the sophisticated antitrust reader will, by now, have seen that the problems that are central to these cases are not specific to two-sided markets theory, and might have been approached under classic antitrust doctrine. Take Groupement des cartes bancaires. The gist of the case was that some banks were free riding on others: whilst the payment system required members to invest in the costly acquisition segment, most banks only wanted to enter the lucrative issuing segment of the market. Such free-riding (or cream-skimming) dynamics are not peculiar to payment systems and can be encountered in many industries, including for instance in distribution networks where opportunistic retailers attempt to free ride on before and after-sales investments made by others. And for decades, antitrust law has dealt with free rider issues in contractual relationships. With this background, the added value of the detour by two sided markets theory is unclear.

Likewise, Amex seems to owe intellectually as much to behavioral economics - which are not mentioned once in the ruling - as it does to two-sided markets theory - which gets a whole host of references. ${ }^{160}$ After all, by allowing merchants to steer cardholders, the Court hoped that cardholders could be nudged into using less expensive networks, even though these networks might have offered them lower cardholder rewards.

${ }^{158} I d$., at $\$ 243$.

${ }^{159}$ Finally, it ought to be noted that merchants might benefit from MIFs because they grow the cardholders base on the other side of the market. This is, in particular, true if installing card terminals and concluding agreements with acquiring banks involves heavy fixed costs. In such cases, merchants might be better off, despite the higher fees, because the increased number of cardholders allows them to achieve scale economies. The Court ruling does not address this issue.

${ }^{160}$ Moreover, the Court manifestly brushed aside a number of important two-sided markets models, and preferred to substantiate its analysis with empirical data. 
Second, both the US and EU cases illustrate how multi-sided markets restore the welfare tradeoffs debate. As many economists have noted, in two-sided markets there are at least two components to look at: the platform's total output and the surplus that accrues to parties on both sides of the platform. ${ }^{161}$ The upshot is that authorities will often be called to choose between total welfare and consumer welfare. Though this is an age-old conundrum, ${ }^{162}$ the growing ubiquity of two-sided markets makes the discussion on welfare tradeoffs even more acute (especially if only on side's consumer surplus is taken into account).

For the moment, the EU and US cases display no clear policy trend on the welfare tradeoffs. In Groupement des cartes bancaires, the Court appears to have favored platform output. Indeed, as the Court itself accepted in Groupement des Cartes bancaires, the fee system undoubtedly reduced the surplus of some members of the association on the issuing side of the market. ${ }^{163}$ However, despite this adverse distributional effect, the Groupement des Cartes bancaires Court insisted that the measures at stake aimed at fostering investments on the acquisition side of the market. In contrast, in MasterCard, the Court leaned towards a consumer welfare standard. The MasterCard Court did not require any proof that the MIFs restricted platform output. It simply considered one side of the platform, holding that a price increase on one side of a platform was sufficient to prove anticompetitive effects. ${ }^{164}$ This schism is unfortunate. By favoring different objectives in Groupement des cartes bancaires and MasterCard, the Court seems unable to articulate a clear vision of the goals of competition policy. Things do not seem

161 There is no agreement on how common or uncommon such a result might be. See Glen Weyl, The Price Theory of Two-Sided Markets, at 26 (December 2006) (unpublished manuscript), http://economics.uchicago.edu/pdf/Weyl_011507.pdf, (Weyl suggests that these objectives often contradict themselves). See also Rochet \& Tirole, supra note 19, at 1005, (Rochet and Tirole's model yields different results. They conclude that often the profits of all parties to a platform are proportional to the total volume of transactions that take place). At the very least, economists agree that in two-sided-markets a price rise on one side can, for a given price level, have opposite effects on consumer surplus and output. In that regard, see also Parker \& Van Alstyne, supra note 33, at 1497.

162 The issue was notably central to Robert Bork's famous “The Antitrust Paradox". Bork, supra note 16 , at 110 .

163 See Case C-67/13 P, Groupement des cartes bancaires v. Commission, not yet published, at $\S 66$ (September 11, 2014).

164 Case C-382/12 P, MasterCard and Others v. Commission, not yet published, at $\$ 193$ (September 11, 2014). 
considerably clearer on the other side of the Atlantic. In Amex, the Court barely mentioned the tradeoff between platform output and (one side) consumer surplus. Granted, the Court referred to externalities which might ultimately cause retail prices to increase ${ }^{165}$. This suggests that it might favor overall output. That said, the Court also repeatedly insisted on the importance of low prices in the acquiring segment (thus ignoring competition for cardholders). Moreover, it did not pay much attention to the NDPs' effect on overall card use and sales volumes. Both these factors suggest that the Amex Court's main concern was merchants' consumer surplus. Without a more explicit treatment by the Court, however, one is left guessing.

In addition, the narrow consumer surplus standards applied in MasterCard and, presumably, in Amex significantly reduce the applicability of the theory of two-sided markets to competition law. If a price increase on one side of a platform is systematically found to have anticompetitive effects, then the theory of two-sided markets becomes nearly irrelevant for competition law purposes.

To summarize, the four cases that are studied in this section show that the theory of two-sided markets has entered US and European case law. However, in light of the disparities observed on each side of the Atlantic, it is at once apparent that this has occurred in the absence of a clear, explicit and structured framework. ${ }^{166}$ Much remains to be done to properly embed twosided market theory in antitrust policy.

\section{B. CASES WHERE THE THEORY WAS NOT (CLEARLY) TAKEN INTO ACCOUNT}

Two-sided markets were most certainly present well before economists discovered and theorized them. If this is the case, the literature suggests that, without the benefit of theories of two-sided markets, authorities and courts may have committed decisional errors whilst enforcing the antitrust laws.

In what follows, we focus on two iconic US and EU antitrust cases in the areas of coordinated and single firm conduct. We find that the theory of two-sided markets would probably not have

\footnotetext{
${ }^{165}$ United States of America et al. v. American Express Company et al., No. 10-CV-4496 (NGG) (RER), at 114 (United States District Court Eastern District of New York, February 19, 2015).

166 This is in line with previous papers, which document EU cases where the theory was mentioned, the markets were characterized as two-sided, but where this seemed irrelevant to the eventual decision. See Filistrucchi et al., supra note 55, at 10.
} 
significantly affected the general outcome of these cases and that authorities often used proxies or rules of thumb that approximated what is today known as the theory of two-sided markets.

\section{Single FIRM CONDUCT: MicROSOFT IN THE US AND THE EU}

The Microsoft case is one of the most high profile cases in US and European antitrust history. In the US, ${ }^{167}$ the case notably focused on Microsoft's maintenance of its Windows operating system ("OS") monopoly through the exclusion of middleware developers such as Netscape. ${ }^{168}$ The Court of Appeals found that Microsoft had sought to protect its OS monopoly from the platform threat posed by middleware providers. This was achieved through several tactics, such as contractually preventing OEMs from pre-installing rival browsers, integrating Internet Explorer and Windows (notably by removing Internet Explorer Add/Remove utility), attempting to exclude Java, etc. Ultimately, the Court of Appeals upheld large parts of the District Court's ruling which found that Microsoft had unlawfully drawn developers away from rival platforms that might otherwise have challenged Microsoft's OS monopoly.

In Europe, Microsoft was found guilty of excluding rivals from the media player market, through the tying of "Windows Media Player" (hereafter: "WMP") with its dominant OS Windows. ${ }^{169}$ The Commission and the General Court's theory of abusive tying was that with pre-installation of WMP on Windows, Microsoft had made its media player ubiquitous. ${ }^{170}$ Content providers and software developers were induced to use WMP-compatible language. ${ }^{171}$

${ }^{167}$ See Case United States of America v. Microsoft Corporation, 253 F.3d 34 (D.C. Cir. 2001).

${ }^{168}$ Our analysis focuses on internet browsers, even though other types of middleware (such as Java) were also at stake.

${ }^{169}$ See Case COMP/C-3/37.792, Microsoft (24 March, 2004). Microsoft was also found guilty of abuse of dominance for unlawfully withholding essential interoperability information from competing OS manufacturers.

170 See Case T-201/04, Microsoft v. Commission, ECR 2007 II-03601, at $§ 979 \& \S 1037$ to 1040 (September 17, 2007). The Court notably found that rival media players could not achieve similar market penetration either by offering their players free for download ( $\$ 1050$ to 1052) or by concluding deals with OEMs who preinstall Windows (and WMP with it) on the PCs they sell $(\S 1043$ to 1048$)$

${ }^{171} I d .$, at $\$ 983 \& 1060$. 
In turn, this made WMP more attractive to users, creating a "positive feedback loop" 172 which foreclosed rival media players. ${ }^{173}$

Given that software markets are often mentioned in two-sided markets papers ${ }^{174}$, it is worth asking (1.1) whether the American and European Microsoft cases feature two-sided markets, and (1.2) whether the application of two-sided markets theory could have substantially affected their outcome.

\subsection{DID THE US AND EU CASES CONCERN TWO-SIDED MARKETS?}

At first blush, OSs, media players and internet browsers exhibit the basic traits of two-sided markets. The three products sit between end-users and content providers, and there are strong indications that the price allocation set by these platforms can, for a given price level, have an impact on output. ${ }^{175}$

But on closer examination, OS and media players must probably be separated from web browsers. Indeed, OSs and media players exhibit obvious cross-group externalities. On both platforms, users on one side are likely to attach some value to the size and quality of the group that is present at the other end of the platform: ${ }^{176}$ OSs match program and application designers with end-users. And Media players connect users and content providers. ${ }^{177}$ Moreover, for

${ }^{172} I d$., at $\S 1061$ to 1077 .

${ }^{173} I d$., at $\S 988 \& \S 1078$ to 1087.

${ }^{174}$ See Nicholas Economides \& Evangelos, Two-Sided Competition of Proprietary vs. Open Source Technology Platforms and the Implications for the Software Industry, 52 MGMT. SCI., No. 7, 1057-71; Eisenmann, Parker \& Van Alstyne, supra note 50, at 2; Rysman, supra note 4, at 125 .

${ }^{175}$ Economides \& Katsamakas, supra note 174, at 1070.

176 One should not, however, overgeneralize. Although it is probably the case that Microsoft's users value extra applications, this is not automatically the case for all OSs. Similarly, content providers might not value the number of users on the other side of the platform if porting was timeless and free.

${ }^{177}$ Users are likely to value players that allow them to access as much relevant content as possible, while content providers might prefer players that attract the most users, especially if porting content from one player to another involves heavy costs. If porting were timeless and free, content providers could simply choose to develop content for all media players. 
media players and, maybe less clearly so for OS, users and developers will often be prevented from reallocating these platforms' pricing decisions amongst themselves.

But in so far as web browsers are concerned, the existence of cross-platform externalities is less probable. Recall that web browsers sit between several different groups of users, i.e. end users, web developers, and client side codes ${ }^{178}$. With this background, the magnitude of a browser's user base seems indifferent for web developers and vice versa. This is so for a number of reasons. First, most mainstream browsers are compatible with all mainstream client side $\operatorname{codes}^{179}$, users can thus access any website with any browser. Second, websites do not need to be optimized in order to run on specific browsers. As a result, web developers do not have to commit themselves to a particular browser in order to reach out to users. ${ }^{180}$

In contrast, the theory of two-sided markets may become relevant in a web browser environment, when companies use such software as gateways to other services where crossplatform externalities might reappear (for example, Google offers its Chrome browser for free as a way to encourage consumers to use Google's other services, including search; Mozilla earns money by integrating Google's search engine as the default search engine ${ }^{181}$ ) or as a rudimentary OS (this was ultimately the goal of Netscape, ${ }^{182}$ and was initially how Chrome OS

${ }^{178}$ I.e. the language which websites use to interact with clients as opposed to servers).

179 See Comparison of web browsers, Wikipedia, http://en.wikipedia.org/wiki/Comparison_of_web_browsers (last visited July 7, 2015). For example, HTML5 is for all practical purposes, supported by all mainstream browsers, as are most mainstream image formats. Indeed, most of these codes are given away for free, this is for example the case of HTML5. Most of the owners of patents used in HTML5 have committed to royalty-free licensing. See Licensing commitments for HTML Working Group's specifications, W3C Website, http://www.w3.org/2004/01/pp-impl/40318/showCommitments (last visited July 7, 2015); Open Web Platform Milestone Achieved with HTML5 Recommendation, W3C Website, http://www.w3.org/2014/10/html5-rec.html.en (last visited July 7, 2015).

${ }^{180}$ Although some websites may require marginal amounts of optimization to run smoothly on a given browser.

${ }^{181}$ See Brian Palmer, Why Is Microsoft Fighting So Hard Over Internet Explorer?, SLATE (Dec. 17, 2009, $6: 01 \quad$ PM), http://www.slate.com/articles/news_and_politics/explainer/2009/12/why_is_microsoft_fightin g_so_hard_over_internet_explorer.html.

${ }^{182} I d$. 
was meant to function) ${ }^{183}$. In such settings, the two-sidedness of browsers is much clearer. However, technicalities aside, the web browser at play in the Microsoft cases did not possess the fundamental features of two-sided markets, in contrast with the OSs and media players. With this nuanced picture in mind, one might then ask whether the US Court of Appeals and EU General Court cases withstand examination under the theory of two-sided markets.

\title{
1.2 COULD THE THEORY OF TWO-SIDED HAVE AFFECTED THE OUTCOME OF THE CASES?
}

Both the US and European Microsoft cases predate the emergence of the seminal models of two sided markets. ${ }^{184}$ Despite this, the US and EU decisions are broadly in line with the main teachings of the theory, even though they relied on a standard theory of network effects. Both decisions understood that tying-down users on one side of a platform could increase adoption by users on the other side. In other words, the two cases aptly identified the existence of crossgroup externalities. On this later aspect, the language used by the US Court of Appeals is particularly prescient: ${ }^{185}$

\begin{abstract}
"Browser usage share is important [authors' note: here the browser was being used as a rudimentary OS] because, as we explained in Section II.A above, a browser (or any middleware product, for that matter) must have a critical mass of users in order to attract software developers to write applications relying upon the APIs it exposes... The overwhelming majority of consumers will only use a PC operating system for which there already exists a large and varied set of ... applications, and for which it seems relatively certain that new types of applications and new versions of existing applications will continue to be marketed..."
\end{abstract}

In hindsight, application of the theory of two-sided markets in those cases would only have marginally improved the antitrust analysis. Surely, the two sided markets literature could have provided stylized wording to improve the authorities' formal reasoning. It might also have helped substantiate the idea that Microsoft was seeking to become a gatekeeper on the

${ }^{183}$ See Steven J. Vaughan-Nichols, It's 2016, and Chrome OS is ascendant, COMPUTERWORLD (June 18, 2012， 2:18 PM), http://www.computerworld.com/article/2504546/operatingsystems/steven-j--vaughan-nichols--it-s-2016--and-chrome-os-is-ascendant.html.

184 The Commission objected to Microsoft's tying as early as 2001, even though the seminal paper on two-sided markets (Rochet \& Tirole, supra note 19) was only published two years later. See European Commission, Commission initiates additional proceedings against Microsoft, press release (August 30, 2001), http://europa.eu/rapid/press-release_IP-011232 en.htm?locale=en. The same can be said about the US Court of Appeals case which was decided in 2001. See Case United States of America v. Microsoft Corporation, 253 F.3d 34 (D.C. Cir. 2001).

${ }^{185}$ Case United States of America v. Microsoft Corporation, 253 F.3d 34, at 18 (D.C. Cir. 2001). 
multimedia content side of the market, though the facts were rather unsupportive of this theory. ${ }^{186}$

Conversely, the theory could have given ammunition to Microsoft in support of its defense that that tying its OS to its web browser and media player was objectively justified. It has been suggested that tying in two-sided markets can be efficient even if it leads to foreclosure. ${ }^{187}$ Surely such a finding would not have precluded the Court of Appeals or the Commission from affirming liability. On both sides of the Atlantic, objective justifications and efficiency defenses are easily disposed of in single firm conduct cases. Nevertheless, such arguments would surely have complicated the task of the authorities.

\section{COORDINATED CONDUCT: EBOOKS IN THE US AND EU}

The eBooks sector has also been the target of antitrust remedies in the $\mathrm{US}^{188}$ and $\mathrm{EU}^{189}$. In both jurisdictions, antitrust agencies found that Apple and a number of e-Book publishers had unlawfully colluded to undermine Amazon's aggressive pricing strategy.

The factual background of those cases is complex, and thus deserves a preliminary exposition. In 2007, Amazon initiated a $\$ 9.99$ pricing policy for a number of e-Books sold on its platform. Wary that this policy would decimate their margins, e-Book publishers sought to discuss with Amazon a change of their business relationship from a classic wholesale model - where

${ }^{186}$ At the time of the EU ruling in particular, iTunes and Youtube were exploding onto the scene, competing aggressively with Microsoft for content providers and developers. Even though they might not have been substitutes from a users' standpoint, both Youtube and iTunes competed with Windows Media Player on the developer's side of the market See notably WebSiteOptimization, March 2006 Bandwidth Report (2006), http://www.websiteoptimization.com/bw/0603/ ; USA Today, YouTube serves up 100 million videos a day online (16 July, 2006, 9.56pm), http://usatoday30.usatoday.com/tech/news/200607-16-youtube-views_x.htm ; and WebSiteOptimization, July 2007 Bandwidth Report (2007), http://www.websiteoptimization.com/bw/0707/.

187 See Jay Pil Choi, Tying in Two-Sided Markets with Multi-Homing, 26 (NET Institute Working Paper No. 06-04; CESifo Working Paper No. 2073., August 2007), http://papers.ssrn.com/sol3/papers.cfm?abstract_id=936481.

${ }^{188}$ See Case United States of America v. Apple Inc., U.S. 12 Civ. 2862, 2013; and Case U.S. v. Apple Inc, 2nd U.S. Circuit Court of Appeals, No. 13-3741, 2015. In this paper, we only refer to the District Court case, which was affirmed by the Court of Appeals.

${ }^{189}$ See notably, Case COMP/AT. 39.847, E-Books (July 25, 2013). 
Amazon freely set the retail price for e-Books - to an agency model - where publishers would set the retail price themselves. But Amazon refused to migrate to an agency model.

In parallel to this, Apple was preparing for entry in the retail e-Books business. E-Books publishers thus started discussions with Apple, and it soon became clear that Apple's entry offered a unique opportunity to coerce Amazon into the agency model. What happened subsequently is now well documented in antitrust history. E-Books publishers signed agency agreements with Apple. The agency agreements contained MFN (most favored nation) provisions which tied eBooks publishers' hands to Apple and threatened to disrupt Amazon's supplies. In practice, the MFN clause worked as follows: should Amazon continue to sell its e-Books at a loss to Amazon for \$9.99, all eBooks sold on Apple's platform would have to retail at the same price, with the particular condition that Apple would retain a 30\% commission on each sale. Under this contractual arrangement, an e-Book sold to Amazon for \$12.99 (and retailed at \$9.99) would, in effect, have to be "sold" to Apple for \$6.99.

Clearly, any such price would have proved untenable for e-Book publishers. Anticipating dramatic losses, e-Book publishers used this pretext to bring Amazon back to the negotiation table and, ultimately, bury the wholesale model for good. Amazon was left with no other choice but to give in to the publisher's demands or risk being denied access to their e-Books.

Eventually, antitrust investigations were opened in the US and EU. With good reason, agencies levelled antitrust concern at the coordinated tactics employed by Apple and e-Books publishers to foreclose Amazon. The US District Court for the Southern District of New York affirmed liability for horizontal conspiracy under Section 1 of the Sherman Act. The European Commission settled the case with the parties in exchange for demanding remedies.

Interestingly, both cases were decided on the basis of a single-sided market analysis. This could come as a surprise for e-Books seem to fit squarely within the classic definition of a two-sided market. As observed by Jeff Bezos himself, ${ }^{190}$ Amazon's core business consists in bringing

${ }^{190}$ In that respect, a quote from the Amazon's CEO seems particularly relevant: "Ultimately we're an information broker. On the left side we have lots of products; on the right side we have lots of customers. We're in the middle making the connections. The consequence is that we have two sets of customers: consumers looking for books and publishers looking for consumers. Readers find books or books find readers". See Caillaud \& Julien, supra note 3, at 309 . 
together book publishers (in digital format) and readers. ${ }^{191}$ Moreover, beyond industry participants' testimonies, e-Book platforms exhibit many of the characteristics of two-sided markets. The ability to access a large variety of works is of the utmost importance to readers, especially if they must pay for their reading device, which is systematically the case. ${ }^{192}$ Last, it is plausible that an e-Book platform's pricing structure can, for a given price level, affect output. In that respect, recent empirical data adduced by Amazon suggests that consumer demand is highly elastic in the eBook sector ${ }^{193}$, and very slight price reductions might have sizeable effects on the demand of eBooks.

But the greatest pedagogical virtue of the e-Books saga is to illustrate the many difficulties of applied two-sided markets theory. Let us revert to the facts in dispute. From an economic perspective, the impugned agency agreements had the effect of arrogating pricing allocation choices from the platform. The agency agreements thus converted a two-sided market into a one-sided market. But is this, in itself, a source of antitrust concern? Some elements of response may be found in Armstrong's "competitive bottlenecks" model. Armstrong suggests that in industries like eBooks the multi-homing side - in this case the publishers - will face monopsony prices to serve the exclusive users of each competing platform - in this case the readers. ${ }^{194}$ In turn, the model predicts that the monopsony gains achieved over publishers will

191 In doing so, they reduce searching and transport costs for consumers, and they allow publishers to enjoy enhanced benefits stemming from the long tailed distribution of revenues (publishers no longer need to decide how many books should be printed and no longer need to store books before they are sold). In that respect, having as wide a library as possible is crucial for platforms to maximize revenues. See Chris Anderson, The Long Tail, WIRED, (October 2004), http://archive.wired.com/wired/archive/12.10/tail.html?pg=1\&topic=tail\&topic_set.

192 On the other side of the Amazon platform, it is unclear how much publishers value the number of users. Indeed, multi-homing might be a particularly attractive option for publishers due to the presumably low cost of porting a book from one medium to another.

${ }^{193}$ See the following statement published by Amazon. Amazon, A Message from the Amazon Books Team, http://www.readersunited.com/.

${ }^{194}$ Armstrong, supra note 20, at 677. Alternatively, one could speculate that Amazon was trying to change the price that customers were willing to pay for an eBook and ultimately force publishers to adapt their prices. It is also plausible that part of the loss that Amazon made on some eBooks was in part compensated by revenue from other, more profitable, eBook sales, by revenue from its Kindle or by advertising revenue. As far as revenue from its Kindle reading device is concerned, see Germain Gaudin \& Alexander White, On the Antitrust Economics of the Electronic Books Industry 3 (September 24, 2014) (unpublished manuscript), http://papers.ssrn.com/sol3/papers.cfm?abstract_id=2352495. Gaudin and White who show 
be transferred to readers, and that a two-sided market setting should thus be particularly favorable for consumers.

Is this, in itself, sufficient to justify concern against agency contracts in multi-sided industries? The likely answer is no. The fact that two-sided "competitive bottlenecks" might yield significant welfare benefits does not imply by necessity that one sided markets cannot bring equal welfare improvements. In that regard, Gaudin and White offer a model that compares welfare under agency and retail models. ${ }^{195}$ Their findings are ambiguous. ${ }^{196}$ In short, the welfare consequences of multi-sidedness v. one-sidedness remain poorly understood.

\section{SUMMATION}

To close our review of this second sample of decisions, several cross-case remarks are in order. For a start, it cannot be conclusively affirmed that two-sided markets were at stake in all those cases. This is most apparent in the e-Books case, where platforms are probably two-sided markets under the wholesale model but not under the agency model. Here, it is a platform's contractual arrangements that determines whether a market is two-sided. Likewise, in Microsoft, media players and OSs seem to fall neatly within the classic definition of two-sided markets, but this is not the case of neighboring products like web browsers.

More fundamentally, the primary challenge for authorities is not so much one of properly ascertaining whether two-sided markets are stake, but rather one of determining if a two-sided market analysis is relevant to the outcome of a case. In that respect, both legal and economic institutions can limit the theory's relevance. As far as the legal framework is concerned, caselaw constraints on the admissibility of economic evidence or on the formulation of efficiency defenses might limit the usefulness of the theory of two-sided markets in real life cases. Suppose that Microsoft's foreclosure of rivals had been deemed efficient by economists, would authorities have changed their decisions? The answer is far from clear. Conversely, economics might often provide ambiguous answers to concrete problems. Take the $e$-Books cases. Gaudin

that eBooks and readers are complementary goods and that their prices should always be looked at together. As far as advertising is concerned, see Amazon's web page for advertisers http://services.amazon.com/content/product-ads-onamazon.htm/ref=footer_pads?ld=AZPADSFooter.

${ }^{195}$ Gaudin \& White, supra note 194.

${ }^{196} I d$. at 22. 
and White's model suggests that the benefits of agency versus wholesale models depend on whether a retailer (Amazon or Apple in this case) holds a monopoly over a complementary good (the e-Book reader). Wholesale is preferable when the retailer has a device monopoly, while Agency is superior when this is not the case. ${ }^{197}$ This raises vexing questions for authorities. Are Amazon's Kindle and Apple's iPad competitors? If not, do the companies have some form of monopoly power over their devices? Furthermore, Gaudin and White assume that publishers are not colluding, which goes against the facts of the e-Books cases. ${ }^{198}$ If one assumes that publishers are colluding, then the findings of Gaudin \& White's model no longer hold. On the contrary, agency agreements may be looked at as facilitating devices that promote horizontal collusion at publisher level. ${ }^{199}$

At this juncture, it should be pointed out that most of the two-sided markets scholarship points in the direction of a relaxation of antitrust enforcement (the most obvious example being the potential justifications for below cost pricing in two-sided markets). Not unlike Chicago school arguments in their time, the theory is often invoked as a means of defense against antitrust theories of harm. However, this need not be the case. As has already been mentioned, turning a two-sided market into a one-sided market might in some cases be used to remove pricing momentum from a platform in order to facilitate a horizontal cartel. The e-Books decisions offer an illustration. With the conversion of Amazon to an agency model, publishers regained control over prices and with it the ability to better detect potential deviations from collusion, be it explicit or tacit (the facts suggest that e-Book publishers were reluctant to compete on prices $\left.^{200}\right)$. The theory of two-sided markets thus also has the potential to help authorities understand why a given business conduct might be anticompetitive - something which has largely gone unnoticed. ${ }^{201}$

${ }^{197} I d$.

${ }^{198} I d$., at 21.

199 See Posner, supra note 16, at 88; See also Bruno Jullien \& Patrick Rey, Resale Price Maintenance and Collusion, 38 Rand J. Econ., Issue 4, 983, 983-1001 (2007).

${ }^{200}$ See Case United States of America v. Apple Inc., U.S. 12 Civ. 2862, 2013.

${ }^{201}$ See Massimo Motta \& Helder Vasconcelos, Exclusionary Pricing in a Two-Sided Market (CEPR Discussion Paper, No. 2012), http://www.cepr.org/active/publications/discussion_papers/dp.php?dpno=9164. 
A last remark is that authorities seemed to intuitively grasp the key findings of the theory of two-sided markets - such as the importance of cross-platform externalities - even though their decisions were not anchored in formal two-sided markets reasoning. This is abundantly clear in the US and EU Microsoft cases. And this begets the question of whether improved two-sided markets models might have brought anything useful to the resolution of such cases, beyond raising decisional costs.

\section{CONCLUSION}

The past ten years have seen a surge in two-sided market papers. A by-product of this evolution has been to whittle away the relevance of one of the theory's basic assumptions - i.e., the unavailability of Coasian bargaining. But this is not all. The literature today displays a jungle of competing two-sided market models. And just as Jean Tirole once lamented with regards to industrial organization as a whole, there is often little to help authorities choose between these models. ${ }^{202}$ As models become ever more idiosyncratic, the theory of two-sided markets risks leaving both authorities and firms in difficult situations; the former because for every case they will have to choose between competing models and the latter because they might be left with very little legal certainty.

These limitations should not, however, discredit the theory's practical contributions in modern antitrust policy. In a world where multimedia platforms are increasingly ubiquitous, the theory of two-sided markets offers a unique framework to understand the dynamics of market competition. In the cases discussed in this paper, the theory often assisted the authorities in understanding the concrete supply and demand conditions on both sides of platforms. The theory also encouraged authorities not to apply existing legal tests mechanically to two-sided markets - think of the SSNIP test in US First Data and Amex cases, and the Court's analysis in the EU Groupement des cartes bancaires case. These are positive contributions.

Despite this, challenges remain. First, in rule-making contexts, courts and authorities will have to draw legal implications from a theory whose policy conclusions are (i) not always consistent and (ii) often challenge established antitrust doctrine. From an economic point of view, there is still some disagreement concerning the theory's finer points (notably what constitutes a two-

\footnotetext{
202 Tirole, supra note 17, at 3 ("“[I] do not want to overemphasize the practical contributions of the theory... it has done little to help practitioners distinguish between competing theories. But it definitely has practical content").
} 
sided market) and how it should be implemented. In this paper we notably report divergent views concerning the implementation of the SSNIP test, the welfare implications of interchange fees, the desirability of fragmentation in software markets, the optimal contractual arrangements for the distribution of eBooks, etc. From a legal point of view, the theory confronts courts and agencies with the necessity of choosing a welfare standard, so as to solve the various trade-offs and distributional choices that will occur in real-life, two-sided markets cases. In the EU, the upper courts have to date refused to ascribe a clear welfarian rationale to the competition rules. Instead, in case after case, they have obscured the question, with abstract references to public-interest goals or to the internal market imperative. How long this intellectual charade will continue in the face of the clear welfarian question put forward by twosided markets theory is anyone's guess. In the US, in contrast, the issue is less acute, because courts have not shied away from discussing the welfarian foundations of the antitrust rules.

Secondly, in adjudication contexts, courts and agencies should identify cases where the theory is most relevant. Sometimes, a two-sided analysis will offer little added value because a case's key issues are not specific to two-sided markets or because one can grasp most of the theory's potential contributions without explicitly referring to it. As is often the case with antitrust decisions, a full-blown two-sided markets analysis risks increasing decisional costs and should therefore be used sparingly - that is, only when it is clear that it can bring an important contribution to their decision.

To summarize, although in many cases the theory has a strong explanatory value, it is far from cohesive at this stage. If, as many economists advocate, the theory of two-sided markets is to be further implemented by competition authorities, a necessary prerequisite is that it be sufficiently streamlined. Further research is therefore needed in order to better turn theory into policy. 


\section{APPENDIX I: COMPARISON OF POTENTIALLY TWO-SIDED MARKETS}

\section{A. PAYMENT SYSTEMS}

- Rochet and Tirole:

Page 648. Yes, if three conditions are met: no surcharging; if platform's MIF is passed through to cardholders and merchants; and if dual-pricing system doesn't lead to transaction costs.

- Evans and Schmalensee:

Implicit in paper that payment systems are two-sided markets; many references to them as examples; no mention that they might not be two-sided markets in some circumstances.

- Rysman:

Page 126. Yes.

\section{B. VIDEO GAMES}

- Rochet and Tirole:

Page 645. Yes. Presumably with similar caveats as in the case of payment systems. For example, under an agency model rather than a retail model, video game consoles might not be true two-sided markets.

- Evans and Schmalensee:

Page 31. Yes.

- Rysman:

Page 125. Yes

\section{OPERATING SYSTEMS}

- Rochet and Tirole:

Page 646. Yes. Usual caveats apply.

- Evans and Schmalensee:

Pages 17 and 32, notably. Yes.

- Rysman:

Page 129. Yes.

\section{ONLINE RECRUITMENT}

- Rochet and Tirole:

Not mentioned in paper. Probably not two-sided; users on both sides of the platform might be able to reallocate the platform's costs among themselves.

- Evans and Schmalensee:

Page 15. Yes.

- Rysman: 
Page 127. Yes.

\section{E. SHOPPING MALLS}

- Rochet and Tirole:

Not mentioned in paper. Maybe not two-sided. Shoppers and retailers are free to reallocate the costs of the platform.

- Evans and Schmalensee:

Pages 14 and 15. Yes.

- Rysman:

Page 125. Yes.

\section{F. ACADEMIC JOURNALS (AUTHORS AND READERS)}

- Rochet and Tirole:

Not mentioned in paper. Probably yes. Academic journals must choose a pricing structure which, presumably, has a strong impact on output. There do not seem to be any obvious ways for parties to bargain around a journal's price structure.

- Evans and Schmalensee:

Page 10. Yes.

- Eisenmann, Parker Van Alstyne:

Page 125. Yes.

\section{G. INDUSTRIAL STANDARDS}

- Rochet and Tirole:

Page 645.Yes, with usual caveats.

- Evans and Schmalensee:

Not mentioned in paper. Probably, standards solve transaction cost problems between producers and patent holders. Both would like to interact, but might not always be able to do so absent standards.

- Rysman:

Not mentioned in paper. Unclear. Buyers value standards which contain the best patents. Patent holders might value standards which contain other strong patents (because they are valuable to consumers).

\section{H. AutomobiLE ENGINES}

- Rochet and Tirole:

Not mentioned in paper. Probably not two-sided markets. Auto owners and refueling stations can reallocate a technology's pricing structure. 
- Evans and Schmalensee:

Not mentioned in paper. People do not buy engines because they want to interact with refueling stations. This example might be closer to traditional complementary goods situations, where the cost of running an engine influences auto owners' initial investment decisions.

- Rysman:

Page 127. Yes. Rysman notes that networks could become more relevant to the auto industry over the next decade.

\section{AIRPORTS}

- Rochet and Tirole:

Not mentioned in paper. Probably not two-sided. Airlines can and do charge different prices depending on the airports of departure and arrival. This suggests that flyers and airlines often reallocate the platform's costs among themselves.

- Evans and Schmalensee:

Not mentioned in paper. Probably yes. Flyers and airlines could not interact without airports.

- Rysman:

Not mentioned in paper. Probably yes. Flyers might value airports that give them access to more connecting flights, while airlines might value airports that give them access to more flyers.

\section{J. SUPERMARKETS}

- $\quad$ Rochet and Tirole:

Not mentioned in paper. Maybe yes. Suppliers and shoppers might not be able to negotiate away the platform's price allocation (if the supermarket controls the retail price). Nonneutrality might be highlighted by the fact that, often, some suppliers pay for shelf placement while others, which are more valuable to consumers, do not.

- Evans and Schmalensee:

Not mentioned in paper. Yes. Shoppers and suppliers need each other; shoppers want to buy goods, suppliers want to sell them. Although these transactions could theoretically take place directly, outside of shops, such a system might be prohibitively expensive (shops significantly reduce transaction costs).

- Rysman:

No. Rysman finds that grocers/supermarkets are not two-sided markets, because suppliers are not paid based on the success of the supermarket with consumers (i.e. how many consumers the supermarket attracts). If one were to assume, as we do, that the number of consumers they draw 
affects the wholesale "price", then supermarkets would be two-sided under Rysman's definition.

\section{K. CONFERENCES}

- Rochet and Tirole:

Not mentioned in paper. Probably yes. A conference's pricing structure might well affect output. Parties cannot readily bargain around the platform's pricing structure.

- Evans and Schmalensee:

Not mentioned in paper. Yes. Conference attendees and speakers want to interact but need a venue to do so effectively.

- Rysman:

Not mentioned in paper. Yes. Conference attendees value quality speakers, while speakers probably value high profile conferences with many attendees.

\section{FRANCHISING (ABSENT RPM)}

- Rochet and Tirole:

Not mentioned in paper. Whether or not a franchise's price structure affects output might depend on whether it controls the prices charged by franchisees. Without RPM, franchisees and customers should be able to bargain away the platform's price structure.

- Evans and Schmalensee:

Not mentioned in paper. Unclear. Franchisees and customers would like to interact by selling and consuming goods, respectively. It is unclear to what extent they need franchises in order to do so.

- Rysman:

Page 136. Yes.

\section{COLLECTING SOCIETIES}

- Rochet and Tirole:

Not mentioned in paper. Probably yes. In many instances, artists and consumers cannot reallocate the collecting society's price structure (especially if exclusive licenses are concluded). The price structure chosen by the collecting society might well affect output (parallel with industrial standards and pools).

- Evans and Schmalensee:

Not mentioned in paper. Clients and artists need each other, but could probably not strike deals without collecting societies (due to prohibitive transaction costs).

- Rysman: 
Not mentioned in paper. Probably yes. Artists might value collecting societies that give them the widest exposure (i.e. that have deals with the most broadcasters), while broadcasters might value collecting societies that have the widest selection of artists.

\section{N. HighWAYS}

- Rochet and Tirole:

Not mentioned in paper. Probably not two-sided. Although highways must make price structure decisions (charge vehicles or fuel stations), motorists and fuel stations might be able to bargain around these price decisions.

- Evans and Schmalensee:

Not mentioned in paper. Probably not two-sided. Motorists need petrol stations and fuelling stations need motorists. They do not need highways in order to interact, even it is convenient for motorists to have petrol stations on the highway.

- Rysman:

Not mentioned in paper. Maybe yes. Motorists might, to some extent, value highways that have more/better petrol stations. Petrol stations value highways that have more traffic. 